\title{
STUDIES OF OLFACTORY SENSATION CURVES IN A VENOUS \\ OLFACTORY TEST
}

By

Yosmumo SAITO

\section{From the Department of Oto-Rhino-Laryngology, Kanazawa University Medical School (Director: Prof. B. Toyota)}

In a venous olfactory test, a variation of olfactory sensation in those who were tested was shown as the changes of grasping power of the hand, and these changes were transduced into electrical changes and plotted as curves.

Several types of olfactory sensation curves thus drawn were investigated. Experimental studies proved analysis of these curves to be very helpful in differential diagnosis of olfactory disturbances.

1) In permanent consistency of olfactory substance, the more olfactory substance was injected, the longer duration time was observed, and the proportion of becoming longer in duration time was than that of growing more in olfactory substance.

2) In patient with so-called olfactory nerve disturbances (olfactory epithelial type), according to the degree of lesion of the olfactory epithe- lium, such tendencies as a longer latent time and shorter duration time than normal were observed.

3) In those with pure respiratory olfactory disturbances (morphological type), a tendency of growing shorter in duration time and no striking changes in latent time were experimentally shown.

4) In olfactory disturdance of those with chronic paranasal sinusitis, a much longer latent time was observed. From this fact, this olfactory disturbance was presumed to involve a considerable degree of the olfactory epithelial factor as well as the morphological factor.

5) Patients with olfactory disturbances after head injuries drew a special type of olfactory sensation curve. It was inferred that this type sugg. ested one of the type in central olfactory nerve disturbances.

\section{経静脈性嗅覚検查における嗅感曲線に関する研究}

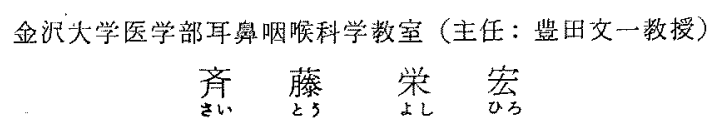

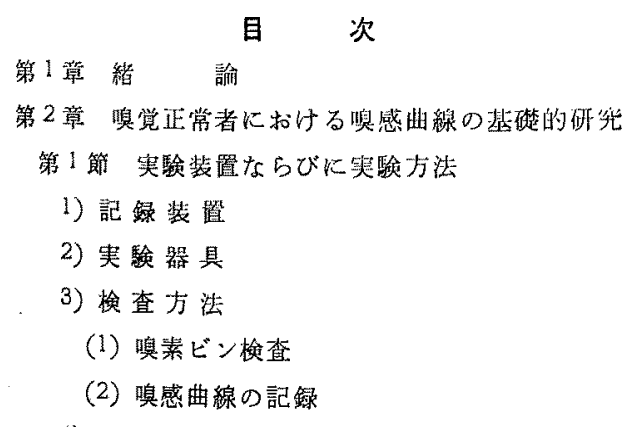

4) 嗅感曲線の読み方
第 2 節 実龆成縝

1）原液 $1 \mathrm{ml}$ を嗅素液として佒用した場合

2) 鮕觉正常者の䍃り返し娭査

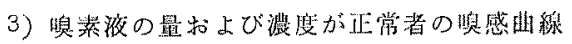

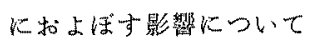

(1) 原澈 $2 \mathrm{ml}$ 使用時

（2）10 倍稀釈液 $2 \mathrm{ml}$ 使用時

(3) 10 倍稀釈液 $5 \mathrm{ml}$ 使用時

(4) 10 倍稀积液 $10 \mathrm{ml}$ 使用時

(5) 100 倍稀釈液 $2 \mathrm{ml}$ 使用時

$11-69$ 
(6) 100 沿稀积液 $5 \mathrm{ml}$ 使湖啮

(7) 100 倍稀釈湤 $10 \mathrm{ml}$ 使用時

第 3 節 考按ならびに小括

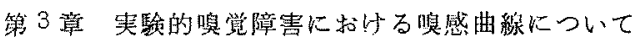

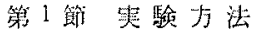

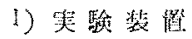

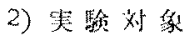

3) 或潟条俳

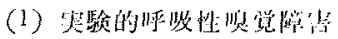

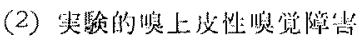

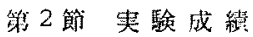

1) 被检者の非操作㭙の成絈

2) 実験的呼吸性咱覚䧊害時の成烧

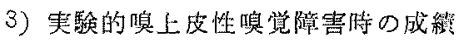

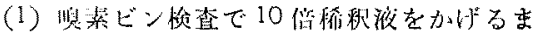
で回後した时守

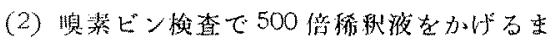
で回隻した胿

第3 䭩 考按ならびに小据

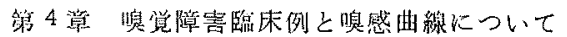

第1節 慢性副學腔炎と嗅覚障害について

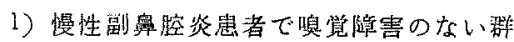

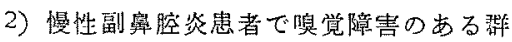

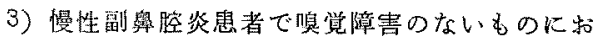

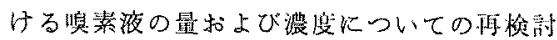

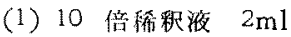

(2) 100 倍稀㷄液 $2 \mathrm{ml}$

(3) 10 倍稀积液 $5 \mathrm{ml}$

(4) 100 倍稀粎液 $5 \mathrm{ml}$

(5) 10 倍稀积洨 $10 \mathrm{ml}$

（6） 100 倍稀骒液 $10 \mathrm{ml}$

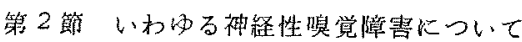

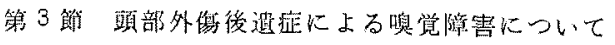

䇷 4 䬶考按ならびに小括

躳 5 整 維湔

\section{第 1 章 粕 馀}

人括よび動物の璂覚について占るくから多くの諸芜に

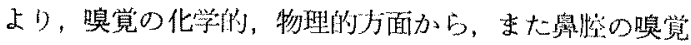

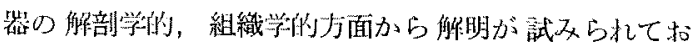

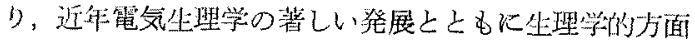
からも検討されつつある，前鼠孔を介して行なわれる， いかわる舅性㬍覚检查は Zwaardemarker 1) が Olfactometer を考案して以来，多くの改良検查法が考案され
てきたが，いすれる操作がかかり繁雑であり比较的简便 な方法としては嗅素ビン検查があるが，本法は哭素漠度 の急激な低下を来たし易く，ために測定値の变動が大き く臨床検查法としてな琎满足できないものである, 1916 年 Kraupa 2), Forschheimer が変性梅毒患者にサル： ルサンを静注した際換覚の起ることを記载し，1930年 Bednär-Langfelder 3)はサルバルサンの他にカンフル 溶液扰よばテレピン油を使用し，これらの蒋剂を静脈内

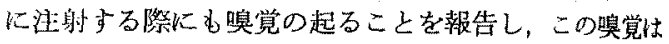
能挀内に注射された嗅素分子が血行を介して唤神経末梢 を刺激するために起ると述べ，かかる嗅覚を血行性㬇覚 と命名した。石川4)は1938年 BednärーLangfelder の㬰験を追試して，血行性嗅覚の存在を認め，さらに鼻 性之血行性の混合唤筧の存在を主張した。これ対し広 瀨5)は1944 年30名の概毒患者にサルバルサンる使用，

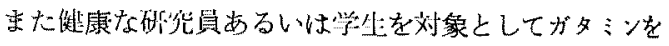

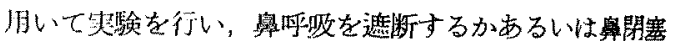

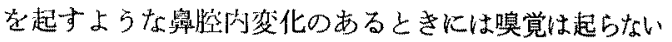
と述べこのよらな嗅感は静脈勺に注射された搝素が辻 胞内に発散し，乎息となつて懙裂に達し唤感を生ずるも ので鼻性㖵覚に他ならないと結論し血行性嗅覚の存在を 否定した，以後血行性咱党の存否をめぐつて我国でも毅 しい諭争がなされ，血行性咱覚説を支持するbのとし て，1956 年長谷部 ${ }^{6)}, 1957$ 年植田 ${ }^{7)}$ ，大沢 ${ }^{8)}$ ，松崎 ${ }^{9)}$ 。

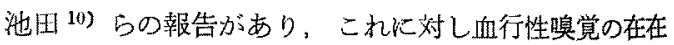
を否定し㠘性嗅覚にはかならないとするるのには，1956

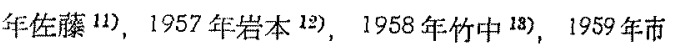
原 14）50報告があり，当教室であ1960年林 ${ }^{15)}$, 渡辽 により血行性嗅覚否定の夹験がなされておる。しかし上 述の論争以来血行を介して生ずる嗅覚は嗅覚機能の検查 法として応用されるよらになり，さらに近年我国炕い $\checkmark$ Thiol 型 Vitamin 誘導体 Thiamin propyl disulfide (ナリナミン) が開発され，嗅覚障害その他の治察 に䏡られるにいたり，治㹉を兼ねて，アリナミンによ

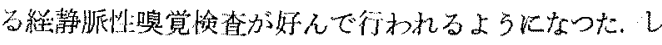

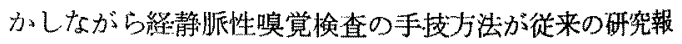

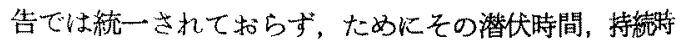
間の測定値が正常人に扎いてもかなりの差があり，また

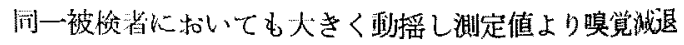
の程庭の判定は图難な状態であつた，1964年，当教室の

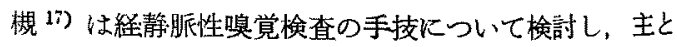
して潜伏時間と搝覚減退について報告した，囷菜液の静

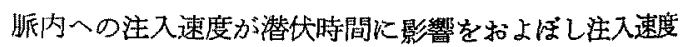


を早めれば潜伏時間が短縮寸る傾问のあること徒来よ り知られているとこるであるが，䞋はさらに検查時の被 检者の呼吸状熊が潜伏時間にかなりの影響を及ぼすこと 飞着目し ${ }^{18)}$ ，综素液の注入速度と被検者の呼吸運動を規 制することにより従来より正確な潜伏時間の測定が可能 であることを迹べた，そして注入速度は $1 \mathrm{ml}$ を10秒間 で可及的等速度で静注し，呼吸は1秒間１呼吸の速さで 軽やかな奥呼收をさせた.アリナミン $5 \mathrm{mg} \cdot 1 \mathrm{ml}$ を咱素 液として使用した際の正常者の潜伏時間は10秒以内で あるとし，上記の万法を改良経静脈性喚覚榆查法と命名

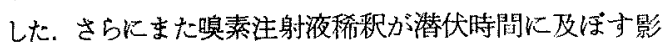
響についても考察し次のような結果を得ている.

従来のアリナミン注射夜をそのまま嗅素注射液として

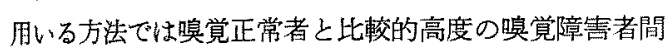
では潜伏時間炕有意の延長が認められ鑑別が可能である が，㖵覚正常者と比較的軽度の嗅覚障害者間では潜伏時 間に鑑別可能な注との差が認められず，両者の鑑別が不 可能なことを指摘し，原因として原液では呼気に放出さ れる搝素が急激に高濃度となり，ために雨者間に差が出 てこないのとと考え，その詨策として注射咱素液を10 〜100倍に稀釈することを考案した，即ち軽度鄙敩障害 者の判定には10〜100倍稀釈液を, 高度嗅覚障害者の判 定には原液を用いることが有利であると結論した。

さて上述の改良経静脈性嗅覚検查以上り，潜伏時間が かなり正確に測定できるよらになつたが，潜伏時間は本

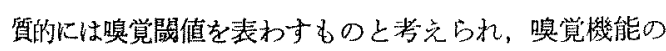
一部分にすざず唤覚機能をさらにくわしく碀明するに は，潜伏時間のみならず穆感発来上り消失までの嗅感持 続時間についても検討する必要がある。経静脈性喚賞检 查に敊ける潜仗時間に関しては今迄にかなりの報告があ るが，持綕時間に関する報告は非常に少なく本邦におい ては石川 (1938) がカンフル溶液扣よびサルバルサンを 注射した際生ずる嗅感は数秒ないし数分で数時間におよ

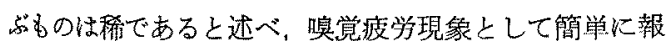
告している，神舁19)(1963) は初めて，絽特脈性唤觉 㭘查に材ける持続時間が嗅覚機能の獬明に重要な要素で あるとし、アリナミン $10 \mathrm{mg} \cdot 2 \mathrm{ml}$ を20秒間で静注し 秒持計で持綕特間を湘定した。

測定方法は喚感発来後 10 秒每に被検者に深呼吸を俞 じ，呼気に和いてアリナミン貝を感じなくなつた时まで を持綕时閒として，正常者 20 名の測定值は1分〜5分で 平均 2 分 50 秒といら值を得た。ささらに嗅覚減退者では 30 秒 1 分 30 秒, 平均 60.5 秒，咱覚脱失者では口秒 60 秒，耿均 48 秒の成績を得，フリナミン持続特閒の大
なるものは唤粘膜感受性が大であると結論しておる。

この测定䛧の変動を大きくする要因は，譛の指撴した ごとく呼吸速度が被検者により翼なつて和ることにある と推定される，そこで改良释静脈性嗅覚検㚗法の考え方 に彷つて持端特間湘定を行なえば，測定值の変動を小さ くすることが可能ではなかららかと考えた。ささらに単に

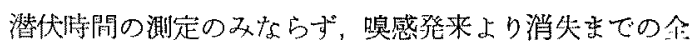
経嵒を捕觉ることができれば，経静脈性嗅覚檢查に上る 墺覚障害の判定恃さらに容易になるのではなかららかと

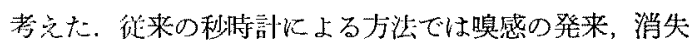
の時点をとらえることは可能であるが，嗅感消長の全程 渦の推移を観察することは困難である。ここに嘪感消長 の全絽過を記録させることができないすのかと考え，そ の記録方法について検討した結果，被検者の握力を利用

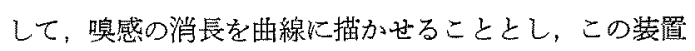
る嗅感記録装置と命名し，これに上り得られた曲線を嗅 感曲線と呼ぶことにした。

この搝感曲線により注射開始から嗅感発来むで，嗅感 が最も強くなつた時，消失した時を一つの曲線として检 榇することが可能となつた。

\section{第 2 章 嗅覚正常者における嗅感曲線の 基礎的研究}

絟静脈性嗅覚検査に批る嗅感の変化の全経過を記録 させ，その得られた曲線から嗅覚障害の程度や原因を追

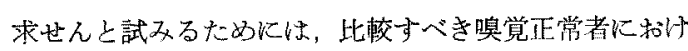
る標潐の曲線を知つて为く必要がある。この月的から、 まず嗅覚代常者について检討することにした。

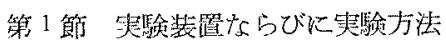

1) 記 録落犆

記録装置は記録機上感压把啊からなり，記録機仕東事 電波工業製の Electronic Polyrecorder Model EPR2T を使用した，喚感の自覚的推移を表現する方法とし て、種々の万法が考党られるがここでは握力の強弱に上

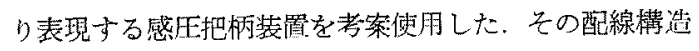
は图1のごとくであり，感主部は板状スプリングの裹面 に炭泰板をはりつけ握力によりスプリングが伸展される ことにより炭素板伸展されその雷気抵抗の变化から回

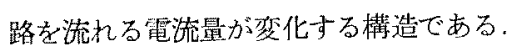

2) 些駼器具

䫝㴽液としてアリナミン注射液 $5 \mathrm{mg} \cdot 1 \mathrm{ml}, 10 \mathrm{mg} \cdot 2 \mathrm{ml}$, $1 \mathrm{ml}, 2 \mathrm{ml}, 5 \mathrm{ml}, 10 \mathrm{ml}$ の注射器, メトロノーム,アリナ ミン㺍素ビン (5000 倍稀釈液, 1000 倍稀釈液, 500 倍稀

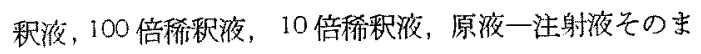




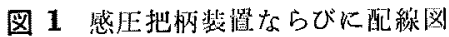

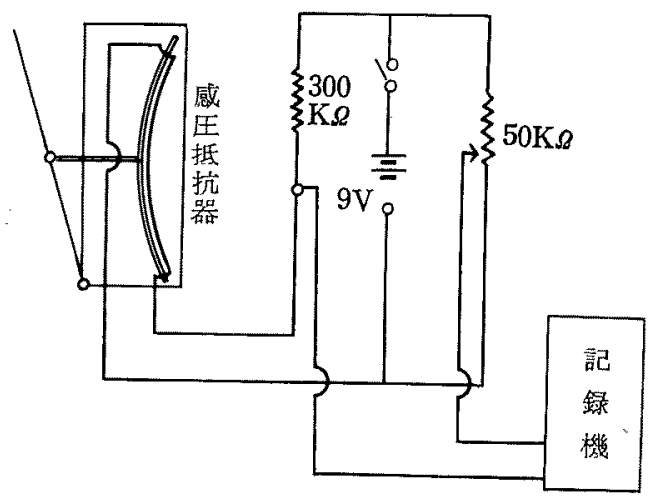

屯)

3) 検查方法

(1) 嗅素ビン検査

嗅覚減退の有無扣よびその程度をあらかじめ知つて拉 くために経静脈性嗅覚検查を行ら前に嗅素ビンに上る鼻 性嗅覚検查を行つた。なおこの䫝素ビン検查はフリナミ ン臭を被㭘者に前もつて知らしめて扔く意義も含んでい る.

嗅素ピンの嗅素液は $100 \mathrm{ml}$ のコルベンに各稀积倍数

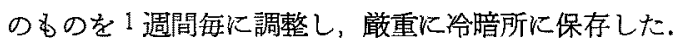
使用する際はそれぞれ $10 \mathrm{ml}$ を $50 \mathrm{ml}$ 着色広ロビンに 入れ密桎し，使用直前に 5 分間， $30^{\circ} \mathrm{C}$ の温湯槽にひた

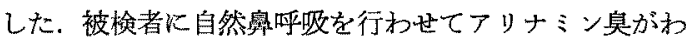
かるむで順次低濃度のものから高濃度のものへとかがせ ていくことにより䫝覚減退の程度を簡単に測定した。

(2) 嗅感曲線の記録

被検者には坐位でメトロ/ームKよる 1 分間 60 回の 音に合せて安静な 稘呼吸（1 呼吸 2 秒間）を行わせてお き，検者は左肘正中静脈にアリナミン嗅素液を10秒間 $1 \mathrm{ml}$ の可及的等速度で注入し被検者の右手掌淕握ら た感止把柄を嗅素液の注入開始の合図と同時に瞬間的に 軽く握らせ，すぐ放し注入開始のマークを記録させた。 嗅感の発来と同時に再び握らしめ嗅感の增強につれて握 力を強め嗅感の最大のときに最る強く据つている状態に させ，臭感の減弱につれて握力を弱めさせ，嗅感の消失 と同時に再び瞬間的に軽く握らせ終末のマークをつけさ せた。

嗅感の終末は一般に不明確で，どの上うな状態に至つ た時を終末点とするがよつて持綕時間に大きな差を生 ずる可能性がある，この検査に㧊いては，呼息毎に持続 的にに拈いを感じていた状熊から連続 3 呼吸に书いを感
じなからた時点をもつて終末と定めた。これ時として 哈感が非常に弱まつてくると数秒位の間隔でに批いがし たりしなかつたりすることがあり終末を何時にしたらよ いのか被検者が迷うことによりおこる誤差を少なくする ためである．な被検者の体位は簡便な外来檢㚗の意味 より坐位をとらせ，注射沉先立つて，鼻息音が聞觉ない くらいの軽い2 秒 1 回の規則正しい呼吸をして㧍ること を確かめ，感王把柄の握り方も良く説明し前むって練習 として一回曲線を描かせた，これは検查後嗅感曲線の形 態について被検者に色ヶと問診するのに便利なためであ る.

記録機の紙送りの速度は毎分 $180 \mathrm{~mm}$ とした。 その他 の注意としては検査室はできるたけ無臭の環境でなけれ ばならず，注射液のアンプルからのつめがや，搝素ビ ン検査は別室で行ない，また注射器からの漏れによる不 注意なアリナミン臭のない上らにし，できるだけ検査室 の換気を良くし，被検者の呼気加ら発するアリナミ溴 を薄めるようにした。

アリナミン液は露光によりかなり唄覚に対する刺㣂性 が減弱するからアンプルから注射器につめたのちはでき るだけすみやかに使用することなどである。

\section{4) 嗅感曲線の読み方}

鮕覚正常者にアリナミン液 $1 \mathrm{ml}$ を注射した場合の注 射開始から嗅感消失までの全経過恃図 2 の如くである。 ここに注射開始から嗅感発来までを「潜伏時間」搝感発 来から最大嗅感までを「最大嗅感までの時間」嗅感発来 から喚感消失をでの時間を「持続時間」と定めた：これ を模式図で表現したものが，図ろである。

さて㖵感曲線に打いては最大懙感の時期は明示される が曲線の高さそのものは嗅感の大きさの絶対值を表わす るのではないのでこの曲線の検討ては，「潜伏時間」, 「最大嗅感をでの時閒」，「持続封閒」の3項について, 各時間的数值をるつて行なつた.

図 2 嗅営正常者の嗅感曲線（嗅案液原液 $1 \mathrm{ml}$ )

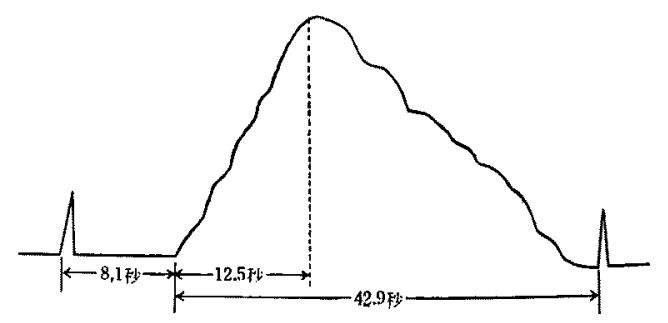




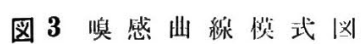

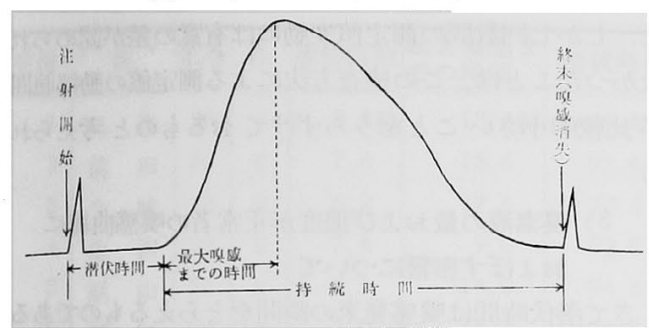

第 2 節 実験成績

1) 原液 $1 \mathrm{ml}$ を嗅素液として使用した場合

（1）呼吸を規制せず秒時計を用いた場合

被㭘者は自覚的に臭覚減退を覚点ず鼻鏡恰查でも咱裂 はきれいに開放しており，ほぼ正常鼻空と思われる者 で，かつ懙素ビン榆査で 5000 倍稀釈液をかぐことが可 能な者で, 21 才から66才までの男子 11 名, 女子 4 名 の計 15 名である.

嗅素液としてはアリナミン原液 $1 \mathrm{ml}$ を左肘正中静挀 より 10 秒閒で可及的等速度で注射し，被検者には普通 の呼收をさせて嗅感発来までの㭙阔，および消失むでの 䦐間を秒特計で測定した。

その検査成績は表 (1) のごとくで平均值およびその95 $\%$ 信頼限界は，潜伏時間では9.6 秒士1.0 秒，持続侍間 では 75.3 秒士28.6 秒であつた，神尾つ検査法とは咱素 液の量・呼吸方法に相違があるが，いずれも持続排問の

表 1 (嗅装液原液 $1 \mathrm{ml}$ )

\begin{tabular}{|c|c|c|c|c|c|}
\hline 症例 & 姓 & 年令 & 性 & 潜伏時間 & 持経時間 \\
\hline 1 & 石 & 43 & $\delta$ & 9.7秒 & 41 秒 \\
\hline 2 & 前 & 23 & q & 6.5 & 168 \\
\hline 3 & 践 & 27 & 古 & 9.5 & 43 \\
\hline 4 & 䏱 & 28 & $\delta$ & 9.7 & 25 \\
\hline 5 & 小 & 23 & 우 & 9.7 & 79 \\
\hline 6 & 京 & 66 & 尔 & 12.0 & 49 \\
\hline 7 & 木 & 37 & f & 11.0 & 30 \\
\hline 8 & 米 & 22 & $\delta$ & 6.4 & 50 \\
\hline 9 & 倉 & 22 & 우 & 12.0 & 43 \\
\hline 10 & 松 & 21 & 우 & 10.6 & 85 \\
\hline 11 & 北 & 21 & $\delta$ & 7.0 & 47 \\
\hline 12 & 浜 中 & 35 & t & 7.8 & 50 \\
\hline 13 & 高橋(芳) & 30 & $\hat{\partial}$ & 12.0 & 180 \\
\hline 14 & 高橋(重) & 42 & $\hat{\delta}$ & 11.0 & 80 \\
\hline 15 & 小 西 & 26 & $\delta$ & 9.6 & 160 \\
\hline & \multicolumn{2}{|c|}{$\begin{array}{l}\text { 平均 } \\
95 \% \text { 倍限 }\end{array}$} & & $\begin{array}{c}9.6 \\
9.6 \pm 1.0\end{array}$ & $\begin{array}{c}75.3 \\
75.3 \pm 28,6\end{array}$ \\
\hline
\end{tabular}

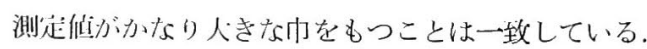

（2）呼吸を規制し嗅感記録装置を使用した場合

被娭者は嗅覚正常な18才から39才までの男子6名, 女子 4 名の計 10 名であり呼吸は 2 秒 1 呼吸の 安静鼻呼 咬とし記録装置により嗅感曲線を描かせた。その検査成 績は表（2）のごとくである. 平汮值およびその 95\% 信 頼限界は潜伏洔間では9.0 秒上0.9 秒, 最大嗅感までの 時閒では 14.2 秒士5.3 秒，持続時間では 54.9 秒士10.3 秒であつた。

表 2 (嗅䒺液原液 $1 \mathrm{ml}$ )

\begin{tabular}{|c|c|c|c|c|c|c|}
\hline 症例 & 姓 & 年令 & 性 & 潜伏時間 & $\begin{array}{l}\text { '最大嗅感 } \\
\text { iでの時間 }\end{array}$ & 持続時間 \\
\hline 1 & 前 川 & 30 & $\delta$ & 8.6秒 & 6.0 秒 & 36.0秒 \\
\hline 2 & 日 野 & 28 & $\hat{\delta}$ & 9.0 & 9.6 & 67.9 \\
\hline 3 & 小 山 & 30 & $\delta$ & 8.6 & 13.3 & 73.3 \\
\hline 4 & 中 橋 & 33 & $\delta$ & 10.6 & 9.0 & 35.6 \\
\hline 5 & 渡 辺 & 26 & $\delta$ & 10.3 & 21.6 & 47.9 \\
\hline 6 & 中品 & 22 & 웅 & 7.6 & 19.3 & 66.6 \\
\hline 7 & 前田 & 32 & 우 & 9.0 & 24.6 & 67.2 \\
\hline 8 & 橋 本 & 25 & 우 & 8.0 & 9.5 & 40.5 \\
\hline 9 & 小呐内 & 18 & 우 & 7.3 & 24.3 & 50.3 \\
\hline 10 & 近 藤 & 39 & $\hat{\delta}$ & 11.0 & 5.6 & 64.6 \\
\hline & $\begin{array}{l}\text { 平 } \\
95 \%\end{array}$ & 均 & & $\begin{array}{c}9.0 \\
9.0 \pm 0.9\end{array}$ & $\begin{array}{r}14.2 \\
14.2 \pm 5\end{array}$ & $\begin{array}{c}54.9 \\
4.9 \pm 10.3\end{array}$ \\
\hline
\end{tabular}

すなわち潜伏封問に比し持続持閂では分散がかなり 大きいが (1)の呼吸を規制ゼず秒時計を用いて测定した 值に比して持続時間は短縮し分散も小さくなつている.

以下の実験は呼吸を 2 秒 1 呼吸に規制して行なつた。

2) 正常者の繰り返し検査

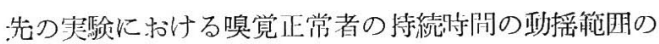
大きい原因は，果たして㭘査方法の不備によるものかあ るいは被検考の個人差によるものかを知るために, 嗅覚 正常なすでに経赫挀性嗅覚椧査に充分習熟している教室 員 5 名を選び繰り返し検查を行なつてみた。これらの被 榆者にアリナミン原液 $1 \mathrm{ml}$ による榆査を 1 日 1 回, 連 続 3 日間行ない検討した. その検查成績は表 (3)のごと くである. 第 1 回目から第 3 回冈までの㗳伏時間の平均 值は， 8.6 秒， 8.1 秒，8.8 秒であり，最大嗅感までの 平均值は 14.0 秒, 12.5 秒, 14.5 秒であり，持続時間の 平均値は，42.4 秒，42.9 秒，49.8 秒で，また各個人に おける 3 回の測定值の動摇範团は潜伏時間では 0.7 秒 1.0 秒で平均 0.9 秒, 最大㕷感までの時間では 1.0 秒 7.4 秒で平屹 4.2 秒, 持続寺間では 6.7 秒〜24.1 秒で平 
均 14.9 秒であつた，以上の成績を分散分析法（二元配

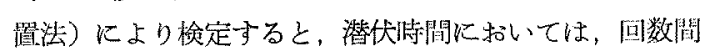
の測定值の変動は Fs $=4.2 \quad \mathrm{~F}(5 \%)=4.46 \mathrm{Fs}<\mathrm{F}(5 \%)$ ， 被検者間の測定值の变動は $\mathrm{Fs}=0.67 \mathrm{~F}(5 \%)=3.84 \mathrm{Fs}$ $<F(5 \%)$ でいずれも検查成績間に有意の差恃認められ なかつた，最大喚感までの時間に打いては，回数閒の測 定傎の夜動は Fs $=0.52 \quad \mathrm{~F}(5 \%)=4.46 \mathrm{Fs}<\mathrm{F}(5 \%)$ ， 被检者間の測定值の変動は $\mathrm{Fs}=5.42 \quad \mathrm{~F}(5 \%)=3.84 \mathrm{Fs}$ $>\mathrm{F}(5 \%)$ で回数間には有意の差を認めないが被検者間 には有意の差を認めた。

持続時間に抢いて，は回数閌の測定值の変動は $\mathrm{Fs}=$ $3.21 \mathrm{~F}(5 \%)=4.46 \mathrm{Fs}<\mathrm{F}(5 \%)$, 被検者間の測定値の 変動は $\mathrm{Fs}=6.66 \mathrm{~F}(5 \%)=3.84 \mathrm{Fs}>\mathrm{F}(5 \%)$ で回数 閐には有意の差を認めないが被检者間には有意の差を認 めた。

表 3 喚営正常者，繰り返し梌查 (嗅素腋 原液 $1 \mathrm{ml}$ )

\begin{tabular}{|c|c|c|c|c|c|c|}
\hline & 姓 & 年命 & 性 & 涾伏時間 & $\begin{array}{l}\text { 最大嗅感 } \\
\text { での時間 }\end{array}$ & 持続特間 \\
\hline \multirow[b]{2}{*}{ 第 } & 棜 田 & 40 & $\delta$ & 8.6 秒 & 7.5秒 & 31.1秒 \\
\hline & 宫 崎 & 28 & $\hat{\jmath}$ & 8.6 & 9.6 & 51.9 \\
\hline 1 & 袙 藤 & 31 & $\hat{b}$ & 9.0 & 19.6 & 52.6 \\
\hline \multirow{2}{*}{ 回 } & 北 山 & 28 & $\delta$ & 9.0 & 22.3 & 33.3 \\
\hline & 槻 & 31 & $\delta$ & 8.0 & 11.0 & 43.0 \\
\hline 目 & F & 均 & & 8.6 & 14.0 & 42.4 \\
\hline \multirow[b]{2}{*}{ 第 } & 梅 & 40 & 3 & 8.3 & 5.3 & 34.3 \\
\hline & 宮 崎 & 28 & $\delta$ & 8.0 & 14.0 & 57.3 \\
\hline 2 & 弯 藤 & 31 & $\delta$ & 8.3 & 18.6 & 42.9 \\
\hline \multirow[t]{2}{*}{ 回 } & 北 II & 28 & $\delta$ & 8.0 & 13.6 & 26.0 \\
\hline & 柣 & 31 & $\delta$ & 8.3 & 11.0 & 54.0 \\
\hline 目 & 平 & 均 & & 8.1 & 12.5 & 42.9 \\
\hline \multirow[b]{2}{*}{ 籍 } & 梅 明 & 40 & $\hat{o}$ & 9.0 & 12.0 & 49.3 \\
\hline & 宮 略 & 28 & 8 & 9.0 & 17.0 & 58.6 \\
\hline 3 & 洂 藤 & 31 & 8 & 9.0 & 17.0 & 67.0 \\
\hline 国 & 北 III & 28 & $\delta$ & 8.0 & 16.6 & 35.9 \\
\hline \multirow{2}{*}{ 目 } & 柣 & 31 & $\delta$ & 9.0 & 10.0 & 38.0 \\
\hline & 平 & 的 & & 8.8 & 14.5 & 49.8 \\
\hline
\end{tabular}

すなわち嗅覚閾值を表わすと考えられる潜伏時間にお いては，この検榃法に扎いてはその測定値の動摇籁围が 少なく，嗔覚疲労が関係すると考えられる最大嗅感まで

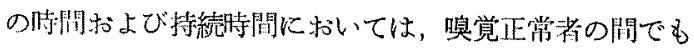

各被检者間にかなり大さな差が存在することがわか た，しかし回数䦥の測定值変動には有意の差が認められ なからたことは，この愉查方法による測定值の動摇範围 が比較的小さいことをららずけて扰るすのと考克られ る.

\section{3) 矈素液の量括よび濃度が正常者の矈感曲線似 拈よぼす影響について}

さて潜伏時閒は嗅感発来の瞬間をとらえるるのである から輢素量に恃特增量する必要をみとめないか，最大

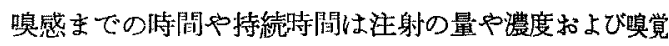
疲学現象に大きく影響されるるのと考克られ，注射量を 增量することにより，疲労現象の影響による結果がより 著明にあらわれる可能性る考光られるので，注射㖡の量 おょび濃度の影響について検討することにした。しかし て正常者のそれぞれの量拉よび濃度に猢るる標準の值が 確立されるならば，それらと病的愪感曲線とを比較する ことによりオージオグラムと怙ける层音采難聴と感音采 難聴の鑑別猃断のごとく，嗅覚障害の分類，もしくは病 型の鑑別診断が可能となるかもしれないと考点今後の実 験研究を進めることとした。

（1）原液 $2 \mathrm{ml}$ を㖵素液として使用した場合 (以下何倍稀釈何 $\mathrm{ml}$ と記す)

被検者は鼻疾患を認めないアリナミン5000 倍稀积液 㖵素ビンのに打いがわかる一般外来者 20 名(男子13名， 女子7名）であり，これらに今迄述べた検查を行ない獸 感曲線を描かせた。

実験成績の大要は表 (4)のごとくである.

測定值の平均括よびその $95 \%$ 信頼限界は，潜伏時間 7.9 秒土 0.5 秒，最大嗅感をでの時間 12.8 秒土 1.2 秒, 持続時間 69.3 秒土 7.3 秒であつた.

(2) 10 倍稀釈 $2 \mathrm{ml}$

被検者は嗅覚正常な男子 12 , 女子 3 名の計 15 名であ る，成續は表 (5)のごとくである，測定值の平均拈よび その $95 \%$ 信頼限界は，潜伏時間 8.9 秒 \pm 0.6 秒，最大嗅 感までの時間 11.6 秒土 2.5 秒，持綕特閒 50.0 秒土7.8 秒であつた。

(3) 10 倍稀釈 $5 \mathrm{ml}$

被検者は同しく搝觉正常な男子 14 名，女子1名の計 15 名である，成續は表（6）のごとくである，測定值の 平均拈よびその $95 \%$ 信頼限界は，潜伏時閣 10.2 秒士1.8

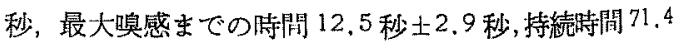
秒士6.5 秒であつた. 
表 4 嵲覚正常者（原液 $2 \mathrm{ml}$ )

\begin{tabular}{|c|c|c|c|c|c|c|}
\hline 症例 & 姓 & 年令 & 性 & 潜伏洔間 & \begin{tabular}{|l|} 
量大嗅感ま \\
での洔間
\end{tabular} & 持続時間 \\
\hline 1 & 日比 & 28 & $s$ & 8.6 秒 & 13，6秒 & 65 ，6秒 \\
\hline 2 & 前 田 & 32 & $q$ & 7.6 & 15.6 & 93.6 \\
\hline 3 & 今 城 & 33 & ? & 6.2 & 17.6 & 70.6 \\
\hline 4 & 淮 田 & 23 & 우 & 7.6 & 9.0 & 52.0 \\
\hline 5 & 裸山 & 26 & 8 & 8.1 & 14.0 & 94.6 \\
\hline 6 & 堀 田 & 26 & $\delta$ & 7.0 & 13.3 & 78.3 \\
\hline 7 & 石 茾 & 30 & $\delta$ & 7.3 & 10.6 & 80.6 \\
\hline 8 & 槜 本 & 25 & 웅 & 7.3 & 19.6 & 59.6 \\
\hline 9 & 波 田 & 17 & 9 & 6.3 & 14.0 & 77,3 \\
\hline 10 & 松 本 & 38 & 우 & 6.6 & 14.3 & 53.9 \\
\hline 11 & 宮 沢 & 28 & $\delta$ & 8.6 & 13.0 & 59.6 \\
\hline 12 & 中 $川 11$ & 33 & $\widehat{o}$ & 8.0 & 11.0 & 46.6 \\
\hline 13 & 伊 藤 & 30 & $\delta$ & 8.6 & 11.6 & 46.2 \\
\hline 14 & 米 䗁 & 37 & q & 9.3 & 11.3 & 90.3 \\
\hline 15 & 藤 沢 & 39 & क & 8.3 & 11.3 & 56.0 \\
\hline 16 & 小川 & 30 & $\delta$ & 10.0 & 9.6 & 72.6 \\
\hline 17 & 野 坦 & 26 & $\delta$ & 8.5 & 11.5 & 92.1 \\
\hline 18 & 北 川 & 28 & $\hat{\delta}$ & 8.3 & 11.0 & 55.6 \\
\hline 19 & 和 田 & 28 & $\delta$ & 7.3 & 12.8 & 72.6 \\
\hline 20 & 藤 永 & 26 & $\delta$ & 7.0 & 11.0 & 68.3 \\
\hline & \multicolumn{2}{|c|}{$95 \%$ 坸 } & & $\begin{array}{r}7.9 \\
7.9 \pm 0.5\end{array}$ & $2.8 \pm 1.8$ & $\begin{array}{c}69.3 \\
69.3 \pm 7.3\end{array}$ \\
\hline
\end{tabular}

表 5 嗅覚正常者 (10倍稀釈液 $2 \mathrm{ml}$ )

\begin{tabular}{|c|c|c|c|c|c|c|}
\hline 症例 & 姓: & 年令 & 性 & 潜伏時間 & $\begin{array}{l}\text { 最大䁚感ま } \\
\text { での時間 }\end{array}$ & 持綉畤閌 \\
\hline 1 & 宫 崎 & 28 & $\delta$ & 8.3 秒 & 10.8 秒 & 57.8 移 \\
\hline 2 & 大 成 & 19 & q & 76 & 23.0 & 60.0 \\
\hline 3 & 堀川 & 26 & $\hat{3}$ & 7.6 & 8.0 & 48.6 \\
\hline 4 & 呍 藤 & 30 & $\delta$ & 8.3 & 9.3 & 34.6 \\
\hline 5 & 大 谷 & 28 & $q$ & 8.5 & 8.5 & 35.5 \\
\hline 6 & 橋 本 & 25 & P & 6.6 & 14.0 & 68,3 \\
\hline 7 & 前 坂 & 31 & $\delta$ & 9.0 & 16.0 & 57.0 \\
\hline 8 & 小西 & 30 & $\delta$ & 9.6 & 10.8 & 69.3 \\
\hline 9 & 石 政 & 30 & $\hat{\delta}$ & 9.3 & 10.6 & 48.9 \\
\hline 10 & 踶 场 & 27 & 8 & 9.1 & 6.5 & 38.5 \\
\hline 11 & 楒 & 31 & $\delta$ & 10.0 & 6.3 & 30.3 \\
\hline 12 & 䙖 田 & 27 & $\delta$ & 10.6 & 8.3 & 38.9 \\
\hline 13 & 湾 辺 & 28 & $\delta$ & 10.0 & 17.6 & 46.6 \\
\hline 14 & 藤 永 & 26 & $\delta$ & 10.3 & 10,6 & 75.6 \\
\hline 15 & 日 比 & 28 & $\hat{o}$ & 10.0 & 14.0 & 41.0 \\
\hline & $5 \%$ 信限 & & & $\begin{array}{c}8.9 \\
8.9 \pm=0.6\end{array}$ & $\begin{array}{l}11.6 \\
.6 \pm 2.5\end{array}$ & $\begin{array}{c}50.0 \\
50.0 \pm 7.8\end{array}$ \\
\hline
\end{tabular}

表 6 临监正常者（10 倍稀釈液 $5 \mathrm{ml}$ )

\begin{tabular}{|c|c|c|c|c|c|c|c|}
\hline 姃例 & \multicolumn{2}{|c|}{ 姓 } & 年令 & 性 & 潪伏時閪 & 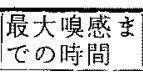 & 持繶崛間 \\
\hline 1 & 小 & 西 & 31 & 占 & 8、3秒 & 6.0 秒 & 88.6 秒 \\
\hline 2 & & 辺 & 27 & $\hat{o}$ & 9.6 & 13.6 & 79.9 \\
\hline 3 & 宮 & 䐀 & 28 & $\hat{\delta}$ & 6.0 & 8.6 & 74.2 \\
\hline 4 & 榴 & 川 & 26 & $\hat{b}$ & 8.3 & 10.6 & 49.9 \\
\hline 5 & 不 & 政 & 30 & 占 & 6.1 & 19.3 & 69.9 \\
\hline 6 & 橋 & 本 & 25 & 8 & 8.0 & 6.6 & 71.2 \\
\hline 7 & 石 & 川 & 29 & $\delta$ & 10.0 & 25.6 & 79.2 \\
\hline 8 & 被 & 田 & 26 & $\hat{o}$ & 10.1 & 10.0 & 76.5 \\
\hline 9 & 野 & 垣 & 26 & $\hat{\delta}$ & 116 & 8.6 & 75.6 \\
\hline 10 & 北 & 山 & 28 & $\hat{\delta}$ & 11.6 & 19.3 & 49.6 \\
\hline 11 & 日 & 比 & 28 & 3 & 10.3 & 13.8 & 65.6 \\
\hline 12 & 中 & 橋 & 33 & $\hat{\delta}$ & 15.0 & 10.3 & 67.3 \\
\hline 13 & 婄 & 藤 & 30 & $\hat{\delta}$ & 19.0 & 11.0 & 68.0 \\
\hline 14 & 藤 & 永 & 27 & $\delta$ & 10.3 & 15.3 & 91.1 \\
\hline 15 & $\mathcal{F}$ & 藤 & 30 & $\delta$ & 9.8 & 9.1 & 64.4 \\
\hline & $5 \%$ & 倍邽 & & & $\begin{array}{c}10.2 \\
10.2 \pm 1.8\end{array}$ & $\begin{array}{r}12.5 \\
12.5 \pm 2 .\end{array}$ & $\begin{array}{c}71.4 \\
1.4 \pm 6.5\end{array}$ \\
\hline
\end{tabular}

(4) 10 倍稀勫 $10 \mathrm{ml}$

被検者は嗅覚正常な男子10名でその成績は或（7）の ごとくである，测定值の平均执よびその $95 \%$ 信頼限界 は潜状時間 9.8 秒士 1.4 秒, 最大嗅感むでの时間 14.6 秒 \pm 7.6 秒，持続時間 124.2 秒土18.0 秒であつた。

表 7 嗅覚正常者 (10 倍稀航液 $10 \mathrm{ml}$ )

\begin{tabular}{|c|c|c|c|c|c|c|}
\hline 症例 & 妙: & 年令 & $|x|$ & 韭伏時間 & \begin{tabular}{|l|} 
最大嗄感ま \\
での时間
\end{tabular} & 特緌㭙睯 \\
\hline 1 & 小酒 & 30 & 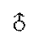 & 7.5 秒 & 4.1秒 & 119.7 秒 \\
\hline 2 & 堀川 & 26 & $\delta$ & 8.0 & 8.6 & 90.6 \\
\hline 3 & 石政 & 30 & 3 & 8.0 & 6.0 & 124.3 \\
\hline 4 & 渡辺 & 27 & $\delta$ & 8.0 & 31.3 & 158.6 \\
\hline 5 & 宮㟷 & 28 & $\delta$ & 9.3 & 12.0 & 145.6 \\
\hline 6 & 日比 & 28 & $\delta$ & 9.6 & 19.3 & 121.3 \\
\hline 7 & 野垣 & 26 & $\delta$ & 11.3 & 6.1 & 127.7 \\
\hline 8 & 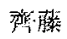 & 30 & $\hat{\delta}$ & 12.0 & 14.0 & 110.6 \\
\hline 9 & 耀目 & 26 & $\delta$ & 12.5 & 34.6 & 158.6 \\
\hline 10 & 北山 & 29 & $\delta$ & 12.0 & 10.0 & 85.0 \\
\hline & o & & & $\begin{array}{c}9.8 \\
9.8 \pm 1.4\end{array}$ & $\begin{array}{r}14.6 \\
14.6 \pm 7\end{array}$ & $\begin{array}{c}124.2 \\
24.2 \pm 18.0\end{array}$ \\
\hline
\end{tabular}

(5) 100 倍稀粎 $2 \mathrm{ml}$

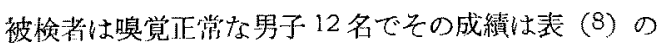
ごとくである． 測定值の平崎およびその $95 \%$ 信頼限界 は潜伏時閒 10.3 秒土 1.3 秒，最大嗅感末での陆閒9.3秒 \pm 3.3 秒，持続時間 43.8 秒士7.5 秒で格つた。 
表 8 览筧正常者 $(100$ 沿㮁粎液 $2 \mathrm{ml}$ )

\begin{tabular}{|c|c|c|c|c|c|c|}
\hline 症例 & 狌 & 年令 & 性 & 潜伏時間 & 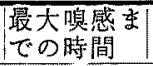 & 持続時間 \\
\hline 1 & 㘫川 & 26 & $\hat{\sigma}$ & 7. . 秒 & 10.3秒 & 50 . 3 秒 \\
\hline 2 & 石政 & 30 & $\hat{\partial}$ & 7.5 & 11.6 & 57.2 \\
\hline 3 & 福田 & 26 & 3 & 8.0 & 9.0 & 51.1 \\
\hline 4 & 日比 & 28 & $\delta$ & 10.6 & 12.6 & 44.6 \\
\hline 5 & 藤氷 & 26 & $\delta$ & 12.0 & 7.0 & 63.0 \\
\hline 6 & 小西 & 30 & $\widehat{\delta}$ & 11.3 & 4.6 & 48.2 \\
\hline 7 & 渡辺 & 28 & $\delta$ & 12.3 & 23.0 & 51.3 \\
\hline 8 & 宮唭 & 28 & $\delta$ & 13.3 & 3.0 & 37.0 \\
\hline 9 & 野垣 & 26 & $\mathcal{\delta}$ & 10.6 & 7.1 & 37.4 \\
\hline 10 & 北旧 & 28 & $\$$ & 13.0 & 9.1 & 27.6 \\
\hline 11 & 槻 & 30 & $\delta$ & 10.0 & 4.6 & 24.6 \\
\hline 12 & 弯藤 & 30 & $\delta$ & 9.0 & 10.0 & 34.3 \\
\hline & $5 \%$ & 均 & & $\begin{array}{c}10.3 \\
10.3 \pm 1.3\end{array}$ & $\begin{array}{c}9.3 \\
9.3 \pm 3.3\end{array}$ & $\begin{array}{r}43.8^{-} \\
43.8 \pm 7.5\end{array}$ \\
\hline
\end{tabular}

(6) 100 倍稀䣋 $5 \mathrm{ml}$

被梌者は嗅覚正常な男子10名で，ての成績は表 (9) のごとくである，測定值の平均牤よびその $95 \%$ 信頼限

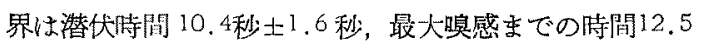
秒士5.2 秒，持続時間 62.0 秒上10.4 秒であつた。

表 9 擅覚正常者 (100倍稀骒液 $5 \mathrm{ml}$ )

\begin{tabular}{|c|c|c|c|c|c|c|}
\hline 㾋: 例 & $|2|$ & 年令 & 性 & 潜伏時閒 & \begin{tabular}{|l|} 
最大嗅感 \\
での時閻
\end{tabular} & 持続時間 \\
\hline 1 & 悹畸 & 28 & $\delta$ & 12.4䄳 & 4.0 秒 & 69.0 秒 \\
\hline 2 & 匆川 & 26 & $\delta$ & 7.6 & 6.0 & 67.0 \\
\hline 3 & 福目 & 26 & $\delta$ & 8.5 & 25.3 & 82.8 \\
\hline 4 & 石政 & 30 & 8 & 8.6 & 6.6 & 71.9 \\
\hline 5 & 小西 & 30 & $\delta$ & 9.0 & 6.3 & 61.4 \\
\hline 6 & 日比 & 28 & $\hat{\jmath}$ & 9.0 & 21.0 & 53.6 \\
\hline 7 & 野垣 & 26 & $\delta$ & 10.0 & 8.0 & 74.6 \\
\hline 8 & 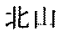 & 28 & $\delta$ & 12.6 & 14.3 & 34.3 \\
\hline 9 & 渡辺 & 28 & $\delta$ & 13.3 & 16.5 & 57.1 \\
\hline 10 & 濟欂 & 30 & 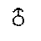 & 13.3 & 17.0 & 48.6 \\
\hline & $5 \%$ & & & $\begin{array}{c}10.4 \\
10.4 \pm 1.6\end{array}$ & $\begin{array}{r}12.5 \\
12.5 \pm 5\end{array}$ & $\begin{array}{c}62.0 \\
62.0 \pm 10.4\end{array}$ \\
\hline
\end{tabular}

(7) 100 倍稀彩 $10 \mathrm{ml}$

被験者住照觉正常な男子 10 名，女子 1 名の計11名て その成績㤬（10）のごとくである，測定値の平均出よ びその $95 \%$ 信頼限界は潜伏時間 10.9 秒士2.4 秒，最大 嗅感までの時間 12.5 秒士5.6 秒，持綕時間 91.8 秒士 12.0 秒であつた。

以上の成䌯を京とめたものが表（11）であるささて替

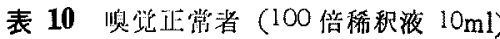

\begin{tabular}{|c|c|c|c|c|c|c|}
\hline 庭例 & 姓 & 年令 & 性 & 潜伏時閻 & 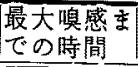 & 特繶時間 \\
\hline 1 & 堿川 & 26 & $\delta$ & 6.0 秒 & 5.6 秒 & 100.6 \\
\hline 2 & 撟本 & 25 & 우 & 7.0 & 11.6 & 93.7 \\
\hline 3 & 石政 & 30 & $\delta$ & 8.8 & 4.0 & 105.6 \\
\hline 4 & 日比 & 28 & $\delta$ & 9.0 & 28.5 & 94.8 \\
\hline 5 & 福田 & 26 & $\delta$ & 9.5 & 12.3 & 115.6 \\
\hline 6 & 率藤 & 30 & $\delta$ & 11.0 & 12.0 & 86.3 \\
\hline 7 & 小西 & 30 & $\delta$ & 11.0 & 4.0 & 108.6 \\
\hline 8 & 野垣 & 26 & $\delta$ & 12.6 & 12.6 & 66.2 \\
\hline 9 & 宮崎 & 28 & $\delta$ & 14.0 & 7.5 & 79.1 \\
\hline 10 & 北山 & 28 & $\hat{o}$ & 18.0 & 15.0 & 62.1 \\
\hline 11 & 渡辺 & 28 & $\delta$ & 13.0 & 25.0 & 98.0 \\
\hline 平 & 10 & 因 & & $\begin{array}{c}10.9 \\
10.9 \pm 2.4\end{array}$ & $\begin{array}{r}12.5 \\
12.5 \pm 5 .\end{array}$ & $\begin{array}{l}91,8 \\
8 \pm 12,0\end{array}$ \\
\hline
\end{tabular}

伏時間は梘の述べたごとく稀釈倍数が大さくなると延長

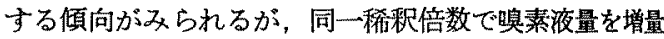
しても明らかな変化は見られない，最大懙感までの時閉 と㬇素液の量や濃度との関係では，たと党ば10倍稀积 で $2 \mathrm{ml}, 5 \mathrm{ml}, 10 \mathrm{ml}$ と增量した場合には，それぞれ11.6 秒，12.5 秒，14.6 秒とわずか化莚長し，また $2 \mathrm{ml} て ゙$ 原 夜，10倍，100倍と稀釈した場合には，それぞれ12,8

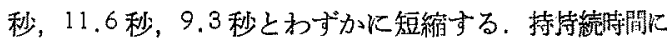

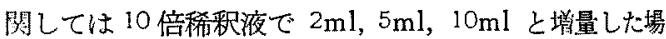
全には50.0秒，71.4 秒，124.0 秒と明らか心延長を䜙 めるが，增曽比にくらへ，持続時閒の延長比はかなり小

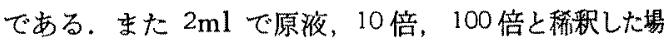
合には 69.3 秒，50.0 秒，43.8 秒と短縮の傾向がみられ 万.

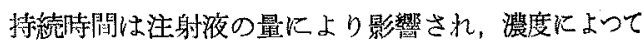
毛かなりの影響をらけることがうかがえる。

表 11 嗅覚正常者の平均值叔よびその95\%信賴限界

\begin{tabular}{|c|c|c|c|}
\hline 塊 素 液 & 潜 伏 時 間 & $\begin{array}{l}\text { 最大嗅感ま } \\
\text { での時間 }\end{array}$ & 持続封間 \\
\hline 原液 $2 \mathrm{ml}$ & $7.9 \pm 0.5$ 秒 & $12.8 \pm 1.2$ 秒 & $69.3 \pm 7.3$ 秒 \\
\hline 10 偣 $2 \%$ & $8.9 \pm 0.6$ & $11.6 \pm 2.5$ & $50.0 \pm 7.8$ \\
\hline 10 倍 $5 \%$ & $10.2 \pm 1.8$ & $12.5 \pm 2.9$ & $71.4 \pm 6.5$ \\
\hline 10 倍 $10 \%$ & $9.8 \pm 1.4$ & $14.6 \pm 7.6$ & $124.2 \pm 18.0$ \\
\hline 100 倍 $2 \%$ & $10.3 \pm 1.3$ & $9.3 \pm 3.3$ & $43.8 \pm 7.5$ \\
\hline 100偣 $5 \%$ & $10.4 \pm 1.6$ & $12.5 \pm 5.2$ & $62.0 \pm 10.4$ \\
\hline 100 倍 $10 \%$ & $10.9 \pm 2.4$ & $12.5 \pm 5.6$ & $91.8 \pm 12.0$ \\
\hline
\end{tabular}

第 3 節 考按

経静脈性嗅覚検查において搝素液の垭脈注射閉始より 


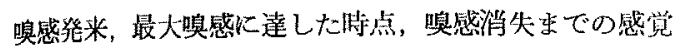
変動を一つの曲綄の形に表現させる嗼感曲線記録装置を 考案陚作しこれより得られた啅感曲線を分析した。

経静脈性嗅覚检查法に和ける潜伏時間に関しては先に 柣力詳細に報告しておるすすなわら检査時の呼吸状態を 1 呼吸 1 秒間の比較的早い鼻呼吸となし咱素液の濃度む 原液，10倍，100倍と稀釈することにより従来に比し比 酸的正確な潜伏時間の測定が可能なことを述心，正常者

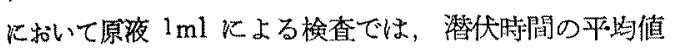
虫 6.7 秒士0.6秒であると述へて执る。私の今回の㬰験

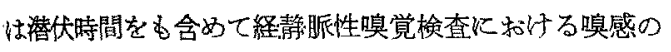
推移の全絽過を追求する目的で行なつたため, 梘が潜伏 時間の正確を期して行なつた 1 秒間 1 呼吸の急速呼吸で は持綕時間のごとく 1 分間以上にも扎よぶ長い間を規則 正しく続けさせることが困難なことを知り，2秒間 1 曲 吸の速度に変えて行なつた。しかしてとの結果，原液 $1 \mathrm{ml}$ に上る検查での潜伏時間の平均值が 9.0 秒士0.9 秒 とわずかに延長してきたが，このことは呼吸速度を2秒

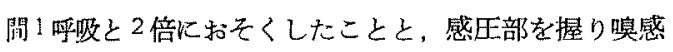
の変化に応して握力を变えわばならないといら被検者に 対する規制条件が堌加したことなどによるるのと思われ る、しかしながらが柣が報告した正常範囲（原液 $1 \mathrm{ml}$ ） 10 移以内といら值にな打含まれておる。

さて経静脈性㖵覚検查に乱て瑱感発来上り嗅感消失 までの搝感の持綕時閒に関しては報告があるが嗅感の発 来後どのよらな過程を経て消失するかという喚感の強さ の推移に関与る矿案発表は今迄にない，本䍜駼に打い。 て，喚感記録装埴を考案したことによりその追跡が初め て容易になつたと考えられる。

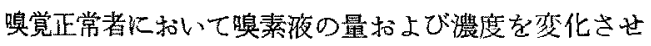
た場合の成績について，5\%以下の危険率でその有意性 について検即した。

潜伏㭙間の开均値に関しては,

(1) 10 倍稀釈で $2 \mathrm{ml}, 5 \mathrm{ml}, 10 \mathrm{ml}$ の間，有意の差が 諰められない。

(2) $2 \mathrm{ml}$ で原液と 10 倍，100 倍稀釈の間，有意の差 が琴坫られる。

(3) $2 \mathrm{ml}$ で 10 倍と 100 倍稀勫の間，有意の差が認め られない.

最大塊感要での時間の平均值に關しては，全ての組み 合せで有意の差が認められなからた。

侍続時間の平均值に関しては,

(1) 10 倍稀釈で $2 \mathrm{ml}, 5 \mathrm{ml}, 10 \mathrm{ml}$ の間，有意の差が
施められる。

(2) 100 倍稀釈で $2 \mathrm{ml}, 5 \mathrm{ml}, 10 \mathrm{ml}$ の間，有意の差が 諗められる。

(3) $2 \mathrm{ml}$ で原液と 10 倍，100倍稀积の閒，有意の美 が琴められる。

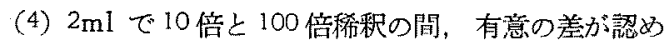
5htst

(5) $5 \mathrm{ml}$ で 10 倍と 100 倍稀釈の間，有意の差が認め bhない.

(6) $10 \mathrm{ml}$ で 10 倍と 100 倍稀釈の間，有意の美が諸 められる。

私の行つた検査では嗅感発来より最大懙感までの㭙間 は，嗅菜液の量と濃度を变化させてもその平均值は 9.3 秒 \pm 3.3 秒 (100 倍稀橎， $2 \mathrm{ml}$ ) 加 5 14.6 秒士7.6 秒 (10倍稀积 $10 \mathrm{ml})$ の間にあり, それらの平均值間には 全て有意の差が認められなかつた，これは経静脈性嗅覚

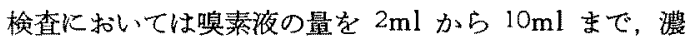
度を原液から100倍稀僠まで变化させてbをれらの平均 值は，95\%までが6秒から23秒の間で最大搝感儿到達 するといらことを示している，今かりに，最大嗅感に達 する時間を23秒とす机ば，嗅素液 $10 \mathrm{ml}$ の場合には最 大喚感に達して後な和子約70 秒以上は肺へ新らしい嗅 素が連続送り込まれていることになる。すなわち䐳刺激 が持綕的に嗅上皮部にな扔加つて技るにもかかわら ず その自覚的嗅锠がある一定の㭙閐で最大澾し以後 除々に強さが弱まり消失するといらことは，嗅覚正活で 鼻疾患を持ためものでは，6秒から23秒以内咱覚の 疲第が表和れてくることが多いと解釈される。

持続時間に関して市原は，原液 $2 \mathrm{ml}(10 \mathrm{mg} 2 \mathrm{ml})$ を 20 秒で注射し正常人の持続時間を1分〜 5 分，平妇2 分 50 秒乙報告している．これ搝感発来後10秒每に被检 者に深呼吸を命じ呼気にお゙いてアリナミン臭を感ずるか 否かを答えさせるという方法を取つたものである、私の 成績では原液 $2 \mathrm{ml}$ 注射時の 持続時閂は 46.2 秒 94.6 秒で平均值は 69.3 秒であり，その95\%信賴限果は 62.0 秒〜76.6 秒で，市原の成縝に比しかなり短かくなり測 定値の動摇は少なくなつている。このことは呼吸状熊の

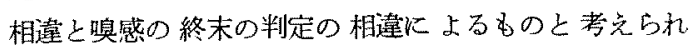
\%.

㖵素液の量および濃度が持続特間におよばす影䜾に関 しては，同じ濃度の嗅素液でその量を増加すれば持続時 間は明らかに延長するが増量比と持続時間の延長比とは 一致せず，持続時閒の延長の比率は増量の比率以下であ 
る。また同じ嗅素液量で濃度を10倍，100倍に稀积す れぱ，持続对閒の短縮する傾向が認められるが，持続持 閒の短縮の比率は稀釈倍数の比率以下である。

\section{第 3 章 実験的嗅鸴障害における嗅感曲線} について

従来鮕覚障害の分類は，楀性または呼吸性喚覚障害と

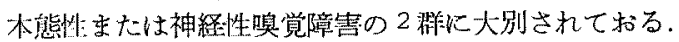
最近市原心形態性, 神経性, 混合性の3群に大別するこ とを提唱し形態性嗅覚障害をさらに 1) 粤内形態の異 常により嗅素が充分に嗅粘膜に到達し得ないるのと 2) 鼻内形態は正常で咱素は充分に到達しても唤粘膜の機能 が障害されて嗅覚滅退をきたしたものとに分類し，神経 性嗅敩障害怯嗅粘膜感受性が高度に障害されるもので形 態性の 2) の強度のものがこれに属し，その間に移行型 があるとしている。 さらに混合性嗅覚障害は神経性嗅覚 障害の中で形態性要因の 強いものであると述べている が，なお充分には理解し得ないものがある。ここに私は 今後の研究の便冝上墺覚障害を炏のごとく分類し研究す ることにした。

1，呼吸性（形態性）嗅覚障害（従来の考兄方々同様 に鼻腔形熊異常により懙素の嗅上皮に到達することがさ またげられるために括こるもの）と従来の神経性嗅覚障 害をさらに二分して，2. 咱上皮性嗅覚障害（嗅上皮そ のものに原因があるもの）と，3. 中枢性嗅覚障害（嗅 上皮上りさらに中枢側に原因のあるるの）とに分け，さ

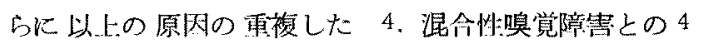
群に分けて検颜することとした。

しかして，これらの 4 群の搝覚障害に和いてそれぞれ 嗅感曲線がどの上らな形をとるるのであるかが明らが されるならば，臨床的に嗅覚障害の鑑別診断が可能とな るのではないかと考光，嗅覚正常者に実験的に一過性の 鮕覚障害をあたえせしめて嗅感曲線を描かせることにし た、人閒に直ちにおこしらる可逆性の嗅覚障害として は，まず嗅裂を人工的閉塞させる呼吸性嗅敩障害之，

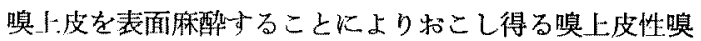

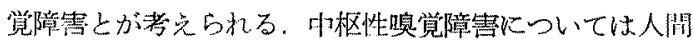
で史験们には行ない得ず，頭部外傷後遗症などに上る唤 覚㜔害患者について別個に检尉寸べきと考えた。

第 1 節 可験方法

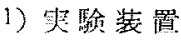

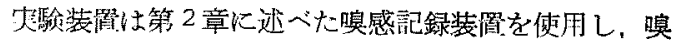
素液は原液 $2 \mathrm{ml}$ を使用した。 その他の策験器具は前章 に述べたものと同じである。

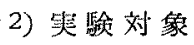

被験者は絽静脈性搝覚检查に習熟した唤覚正常な教室 員で鼾腔形態も鼻鏡検査でほぶ正常な者8名を対象とし た.

3) 実験条件

（1）実験的呼吸性嗅覚障害

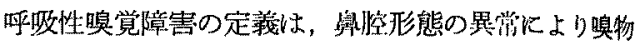
質を含んだ空気が嗅上皮に充分到達し得ないことにより 生ずる嗅覚障害である。臨床的には中鼻甲介の䐺脹，強

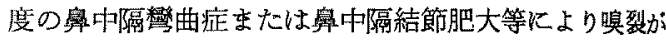
閉鎖された状態と考えられる．そこで私は嗅裂が両儧共 きれいに開放して扣る嗅覚正常者を選び，人工的唡㑡 嗅裂に白色ワゼリンガーゼを挿入して呼吸性嗅覚障害を おこさせることを試るた，鼻腔粘膜は知覚が銧敏である から粘膜麻酔なしにガーゼを咱裂内に插入することは被

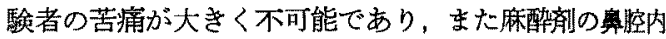

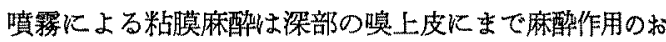

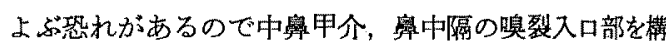
成する面を $2 \%$ キシロカインを唚した綿棒で充分に麻醉 した後，嗅裂にできるだけ深部をで軟零がーゼを拆入し た．㨉入に際しては提子で鼻粘膜を傷つけぬよら滇重に 行なつた。

嗅裂へガーゼを充媜した後アリナミン嗅系ビン検查を 行ならに，500 倍稀䣋ではじめてアリナミン臭を感しる 程度まで嗅覚を減退させることができたが，この方法で はさらに高度に嗅覚障害を杖こさせることはできなから た.

（2）実験的嗅上皮珄喚覚障害

Bednär-Langfelder の報告によれば，喚粘膜に「コ カイン」を染布すれば夓性唤覚は大きな影響をうけ，喚 覚減退または嗅営脱失をきたすが血行性嗅覚は何らの变 化も起こさないとしている，血行性嗅覚の存在が否定的 である現在では，Bednär らが行なつたロカインによる 鮕粘膜麻酔が充分なるのであつたかどうか疑問である. そこで前述の被験者のうち3名で次の予備実験を行なつ たまず嗅上皮麻醉前に嗅素ビン検査を行ない５000倍

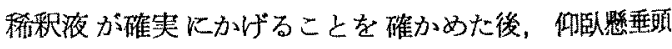
位にして $30^{\circ} \mathrm{C}$ に加温した粘膜表面麻酔视である $2 \%$ キ シロカイン液 $5 \mathrm{ml}$ ずつを左右の 前奥孔から注入し，30 秒間口呼吸を行なわしめて括いた後，坐位に床し裹腔内 麻醥剂を喀出および擤鼻により除去せしめた。この操作 により一時的な悬閉が括こるが，これが去つた後も瞁素 ビン検査では全く嗅感が㧍こらなからだ，嗅覚の回復の 
速发尤，10倍稀釈液がかげる程度までに10〜15分を荘

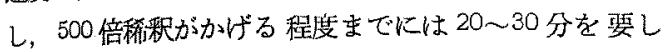
たな蛙上記の条件で得られた嗅覚障慧が，嗅上皮面に 単なる液体を触れさせただけでも拓こり得るのではない かといら㬎念もあつたので, $30^{\circ} \mathrm{C}$ に加温した生理食塩

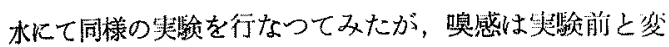
らず暞素ビン梌查で 5000 倍稀噃液をかぐことが四能で あつた。このことから2\%キシロカイン签液注入により 得られた嗅覚障害は嗅上文が䏫酔されたためにしたも のと推定した。

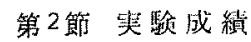

\section{1) 被挨者の非操作時の成續}

拲覚正常な教室員 8 名に鄓素液として原液 $2 \mathrm{ml}$ を使

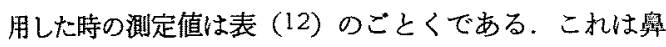

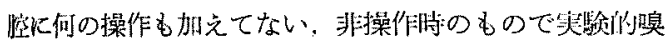

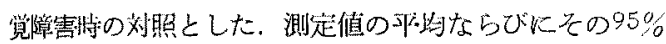
信頼限累は次のとおりである。

\begin{tabular}{|c|c|}
\hline 潜 伏 㸝 間 & 8.3 秒上 0.9 秒 \\
\hline 最大咱感までの時間 & 9.4 秒士 2.6 秒 \\
\hline 持 綕 時 閫 & 73.8 秒土 13. \\
\hline
\end{tabular}

表 12 奏験的䝷覚檤害非操作時（原液 $2 \mathrm{ml}$ )

\begin{tabular}{|c|c|c|c|c|c|c|}
\hline 症例 & 姓 & 年令 & 性 & 潜伏時間 & \begin{tabular}{|l} 
最大䁚感ま \\
|この時間
\end{tabular} & 持続時間 \\
\hline 1 & 石政 & 31 & $\delta$ & 7.3秒 & 4.6秒 & 80.6 秒 \\
\hline 2 & 福田 & 26 & $\hat{\delta}$ & 8.1 & 14.0 & 94.6 \\
\hline 3 & 柣 & 31 & $\hat{\jmath}$ & 7.0 & 11.3 & 78.3 \\
\hline 4 & 江川 & 33 & $\hat{\delta}$ & 9.0 & 7.0 & 46.6 \\
\hline 5 & 宮崎 & 28 & 3 & 9.6 & 10.0 & 59.6 \\
\hline 6 & 齊藤 & 31 & $\delta$ & 7.1 & 6.6 & 72.6 \\
\hline 7 & 野垣 & 26 & $\delta$ & 8.2 & 10.5 & 92.1 \\
\hline 8 & 北山 & 28 & 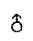 & 9.3 & 11.0 & 65.6 \\
\hline & $95 \%$ & & & $\begin{array}{c}8.3 \\
8.3 \pm 0.9\end{array}$ & $\begin{array}{r}9.4 \\
9.4=2 .\end{array}$ & $\begin{array}{c}73.8 \\
.8 \pm 13.6\end{array}$ \\
\hline
\end{tabular}

2) 实験的呼吸性嗅覚障害時の成績

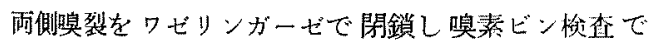

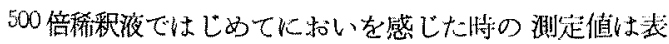
(13) のごとくであり，測定值の班牨 50 よびその $95 \%$ 信 頼限界住次のと扰りである。
潜 伏 搏 衙
9.0 秒止 1.5 秒

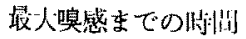
7.4 秒比 2.4 秒

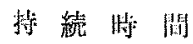
55.0 秒上7.7秒

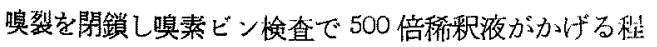
度まで嗅覚減退した時の成績は，非操作封と比較して， 潜伏時間では大きな差は認められず，最大嗅感までの眭

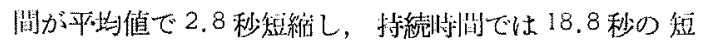
睢を哂好た。

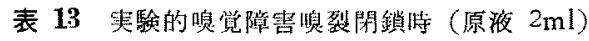

\begin{tabular}{|c|c|c|c|c|c|c|}
\hline 壾例 & 姚: & 年令 & 性 & 潜伏妇關 & $\mid$\begin{tabular}{|l} 
最大嗔感ま \\
での時間
\end{tabular} & 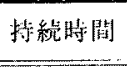 \\
\hline 1 & 不政 & 31 & $\delta$ & $7 、 3$ 秒 & 5.9秒 & 56.1 秒 \\
\hline 2 & 街怕 & 26 & $\hat{\delta}$ & 7.0 & 7.2 & 45.1 \\
\hline 3 & 稀 & 31 & $\delta$ & 8.5 & 5.3 & 48.4 \\
\hline 4 & i:川 & 33 & $\delta$ & 12.0 & 6.0 & 54.1 \\
\hline 5 & 证斯 & 28 & $\delta$ & 10.6 & 7.0 & 71.9 \\
\hline 6 & 洲类 & 31 & $\delta$ & 8.6 & 8.6 & 49.8 \\
\hline ? & 野垣 & 26 & $\delta$ & 7.9 & 13.9 & 65.3 \\
\hline 8 & 北山 & 28 & $\delta$ & 10.8 & 5.3 & 49.4 \\
\hline & $95 \%$ & $\begin{array}{l}\text { 均 } \\
\text { 䇾泿 }\end{array}$ & & $\begin{array}{c}9.0 \\
9.0 \pm 1.5\end{array}$ & $\begin{array}{c}7.4 \\
7.4 \pm 2.4\end{array}$ & $\begin{array}{c}55.0 \\
55.0 \pm 7.7\end{array}$ \\
\hline
\end{tabular}

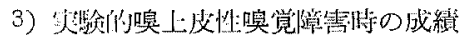

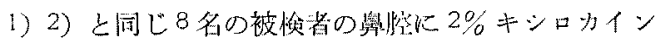

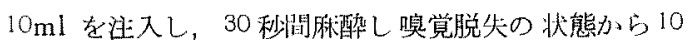

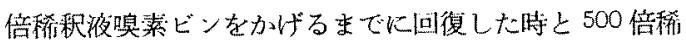

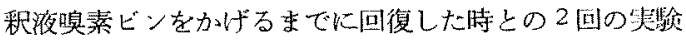

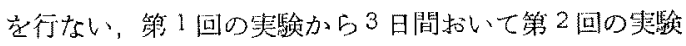

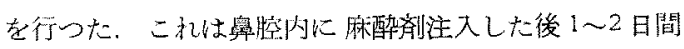

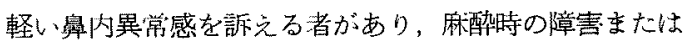
その余効を避けるためである。

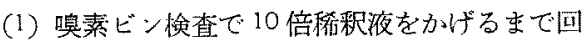
復した時

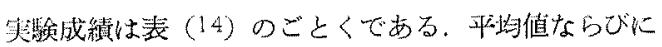
その $95 \%$ 俉頼限界は次のと括りである。
鲨 伏 時 間
15.7 秒土3.1秒
最大舆感までの時闒
8.7 秒土 2.9 秒
持椟 膊: 間
31.5 秒土 3.9 秒

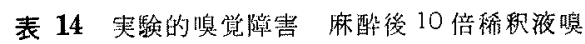
觉可能時 (原液 $2 \mathrm{ml}$ )

\begin{tabular}{|c|c|c|c|c|c|c|}
\hline 空例 & 妵: & 年令 & 性 & 潜伏時間 & $\begin{array}{l}\text { 最大嚊感ま } \\
\text { での㭙 间] } \\
\end{array}$ & 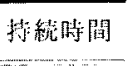 \\
\hline 1 & 炠 & 31 & 3 & 10.8 秒 & 47 利 & 28.5秒 \\
\hline 2 & 石政 & 31 & $\delta$ & 14.2 & 10.0 & 41.8 \\
\hline 3 & 稫山 & 26 & $\hat{3}$ & 13.0 & 6.7 & 34.3 \\
\hline 4 & 秘菜 & 31 & $\delta$ & 13.0 & 10.6 & 28.9 \\
\hline 5 & औ.川 & 33 & 3 & 15.8 & 13.0 & 29.0 \\
\hline 6 & 芴相 & 28 & $\beta$ & 16.6 & 3.3 & 31.9 \\
\hline 7 & 野垭 & 26 & $\delta$ & 21.0 & 9.3 & 29.0 \\
\hline 8 & 北山 & 28 & $\delta$ & 20.8 & 11.8 & 28.8 \\
\hline & $\%$ & & & $\begin{array}{c}15.7 \\
15.7 \pm 3.1\end{array}$ & $\begin{array}{c}8.7 \\
8.7 \pm 2.9\end{array}$ & $\begin{array}{r}31.5 \\
31.5 \pm 3.9\end{array}$ \\
\hline
\end{tabular}


唤上皮を的酔し10 倍稀採液でに招いを感ずる程度に 喚覚娍退をきたした特の平均値は非操作時の平均值と比 較して，潜伏時間では 7.4 秒延長し，持続時間では 42.3 秒短維した．最大嗅感までの㭙間には著るしい差は認め られなからた。

(2) 鄓素ビン検査で 500 倍稀积液をかげるまで回 復した時

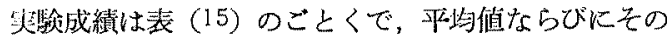
95\%信頼限界は次のと格りである。
潜 伏時闰
11.2 秒土 1.1 秒
最大鮕感までの持間
10.6 秒土 4.0 秒
持続 時間
48.3 秒土 3.7 秒

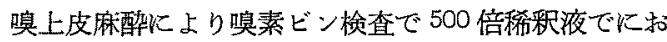
いを感ずる程度にるで嗅覚減退した時の平均値と非操作 䠌の平均值之比較すると，潜伏時間では 2.9 秒延長し， 最大喚感までの時間では 1.2 秒延長し，持続時間では 25.5 秒短縮した。

噢裂を開鎖し同しくく500 倍稀釈嗅素ビンでに扣いをか げるまで嗅覚減退させた時と比較すると潜伏時間では 2.2 秒，最大喚感玉での時間では 4.0 秒長く，持綕時間 では 6.7 秒短かからた。

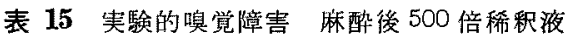
嗅覚可能時（原液 $2 \mathrm{ml}$ )

\begin{tabular}{|c|c|c|c|c|c|c|}
\hline 症例 & 始: & 年令 & 性 & 潜伏時間 & \begin{tabular}{|l|} 
最大嗅感ま \\
での時間 \\
\end{tabular} & 持続時間 \\
\hline 1 & 㭇 & 31 & $\delta$ & 9.2秒 & 9.5 秒 & 53.6 秒 \\
\hline 2 & 石政 & 31 & $\hat{\delta}$ & 12.7 & 10.4 & 48.6 \\
\hline 3 & 福田 & 26 & $\delta$ & 11.6 & 21.0 & 47.0 \\
\hline 4 & 乷藤 & 31 & $\delta$ & 10.1 & 11.0 & 39.5 \\
\hline 5 & 江川 & 33 & $\hat{\beta}$ & 10.5 & 5.0 & 46.3 \\
\hline 6 & 容䆛 & 28 & $\hat{B}$ & 11.3 & 7.6 & 51.1 \\
\hline 7 & 黠垭 & 26 & $\hat{o}$ & 13.2 & 7.8 & 52.9 \\
\hline 8 & 北山 & 28 & $\delta$ & 10.9 & 12.5 & 47.5 \\
\hline & $5 \%$ & & & $\begin{array}{c}11.2 \\
11.2 \pm 1.1\end{array}$ & $\begin{array}{c}10.6 \\
10.6 \pm 4.0\end{array}$ & $\begin{array}{c}48.3 \\
48.3 \pm 3.7\end{array}$ \\
\hline
\end{tabular}

第 3 節 考揬ならざに小括

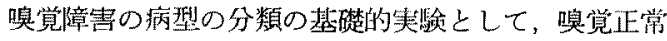
者において实験的比嗅覚障害を作り喚感曲線を記録分析 した。

实験的喚覚障害には，1）呼吸性（形態性）喚覚障害， 2）神経性（鮕上皮性）嗅覚障害想定し，哦吸性噢覚 障害としては両側喚裂にワゼリンガーゼを密に挿入しア リナミン搝素ビン検査で嗅覚の低下した時，神経性嗅覚

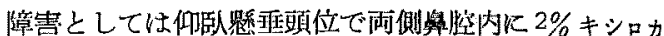
インを注入し，嗅上皮麻酔比よる嗅覚脱失の状態的嗼 覚娍退の程度にまで回復したものを選んだ，鮕裂をガー ゼで充媜する際は麻酥郕を棉俸で中番甲介と中隔面涂 布し，アドレナリン塗布により嗅裂を充分に広げてから 行ない粘膜を傷つけねように注意を払つた，㖵裂を閏鎖 してから一側ずつ嗅素ビン検査を行なつたところ正常者

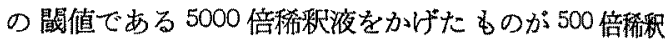
液でようやくかげるまで嗅覚を低下させることができ た。ささらに高度唤覚障害を物こさせんと試みたが不可能 であつた。

嗅上皮麻醉による嗅覚障害には $30^{\circ} \mathrm{C}$ に加温した $2 \%$ キシロカイン $5 \mathrm{ml}$ ずつを笔垂頭位で 両鼻腔に注入する ことにより，嗅覚脱失の状態になでいたらしめ，この状 態から嗅素ビン検査で 10 倍稀釈液が嗅覚可能にまで回 復した時期と，3日後に同様の方法で筃覚脱失から500 倍稀釈液が嗅覚可能にゅで回復した時期とについて釦討 した.

以上の条件・で絟静脈性咱覚検查を行なつた成績を総合 したものは表（16）である。これらの測定值の潜伏时 間，最大咱感までの時間拉よび持続時間の三項目につい て各々の実験間の有意性について $5 \%$ 以下の色険率で強 討した。

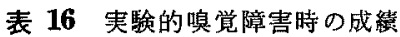

\begin{tabular}{|c|c|c|c|}
\hline & 潜伏時間 & \begin{tabular}{|l} 
最大嗄感ま \\
での時間
\end{tabular} & 持続显間 \\
\hline 非 操 作 時 & $8.3 \pm 0.9$ & $9.4 \pm 2.6$ & $73.8 \pm 13.6$ \\
\hline 咱裂閉鎖洔 & $9.0 \pm 15$ & $7.4 \pm 2.4$ & $55.0 \pm 7.7$ \\
\hline 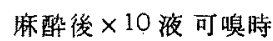 & $15.7 \pm 3.1$ & $8.7 \pm 2.9$ & $31.5 \pm 3.9$ \\
\hline 称酸後 $\times 500$ 液可嗅時 & $11.2 \pm 1.1$ & $10.6 \pm 4.0$ & $48.3 \pm 3.7$ \\
\hline
\end{tabular}

潜伏時間の平均値に関しては

(1) 非操作時 と㖵裂閉鎖時 (500 倍稀釈液喚覚可能) と の間，有意の差が認められない。

(2) 非操作時と麻酔後 10 倍稀釈液嗅覚可能時との間， 有意の差を認める。

(3) 非操作時 と麻酔後 500 倍稀积液嗅覚可能時との 間，有意の差を認める。

(4) 嗅裂閉鎖時と麻酔後 10 倍稀釈液嗅覚可能との間 有意の差を認める。

（5）唤裂閉鎖時と麻酔後 500 倍稀釈液筃覚可能時との 間，有意の差を認める。

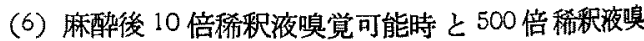


覚可能時との阔，有意の差を諰める。

以上の結果から潜代侍閒に関しては嗅粘膜麻醉の場合

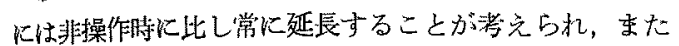
麻醉の程度 (嗅覚障害の程度) に応じて延長の度合が大 きいことが推定される。

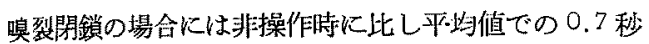
の延長を認めたが推計学的には有意の差が認められなか つたととから，舆素ビン検查で 500 倍稀釈液を嗅覚可能 といら程度の比校的軽い嗅覚郣害では潜伏時間には潘明 な変化はないるのと推定される。な拉高废の障害につい ては実験し得なかった。

次に最大喚感をでの時間に関しては，それぞれかずか な变動がみられたが，推計学的にはいずれの組合せでも 有意の差が認められなかつた。このことは最大嗅感まで

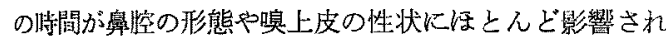
ぬことを意味し，ひいては最大嗅感をでの時間に大きく 影響すると考克られる嗅覚披学現象には，さらに高次の 中枢が関係するのではなかららかと推測される。

持綕特間の平坞值に関しては

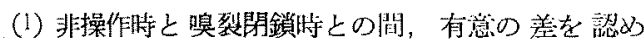
る.

(2) 非操作時と麻酥後 10 倍稀釈液咱覚的能時との間, 有意の差を認める。

(3) 非操作時と麻酔後 500 倍稀釈液嗅覚可能時との

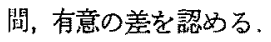

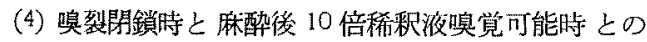
間, 有意の差を誌める。

(5) 㬇裂閉鎖時之麻酥後 500 倍稀粎液噢觉可能時との 間，有意の差があると認めがたい

(6) 麻醉後 10 倍稀釈液嗅覚可能時 と麻酥後 500 倍稀

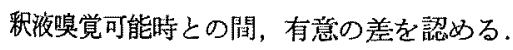

以上の結果から持続時間に関しては，非操作㭙に比し 全例飞短縮の傾向が見られたが，特に嗅上皮麻酔の場合 に外障害の程度に心して短縮の度合が大きいことが推定 される.鮕裂閉鎖時と嗅上皮麻酔㭙とでも500 倍稀釈液 嗅覚可能な此較的軽度の嗅覚障害時では，平均值で後者 が約 7秒より短縮していたが推計学的には有意の差が認 められなかった，さらに高度の㬇覚障害時について検討 すべきであるが些駼的な墺裂閉鎖では 500 倍唤覚可能ま でしか作ることができなかった。

次に以上の結果と嗅覚障害の型てついて述べるならば 1. 呼吸性嗅覚障害比おいては，嗅素ビンで500 倍稀 积液嗅覚可能な此較的軽度嗅覚障害では，潜仗封間は正

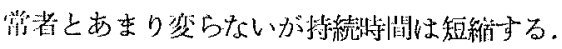

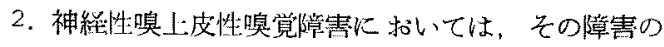
程度に応じて潜伏时間は延長し，持続時临は短縮す る.

3、両者共に椳大喚感までの洔閂に関しては正常者と の間に明らかな変化はみられない。

\section{第 4 章 嗅覚障害臨床例と嗅感曲線について}

前章に扰いて考察したごとく，咽覚㹿害の㤠によって 喚感曲線の形に相違のあることが判明した。すすなかち鼻

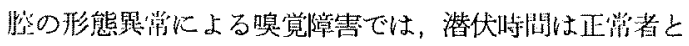
有意の差がなく持続時間の短緶で正常者と有意の差がで てくること.

唤上皮の機能低下による嗅上皮性嗅覚障害では潜伏吋 間の延長，持続侍間の短縮がみられ，これらは䝷上皮の 機能低下の度合に影響されること。

最大嗅感までの時間では有意の差がないことなどであ

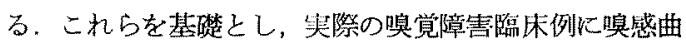
線を応用し㛟討した。

さて，種々の鼻疾患に伴う嗅覚障圊については今まで に多くの研究報告がなされている。

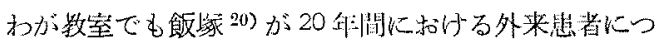
いての統計を報告して扣る。すなわち疾患別にみた慗者 の嗔覚障害を主訴とする比率は, 急性鼻炎では $1.3 \%$ に 又られ，以下慢性単純性鼻炎 $2.5 \%$, 慢性肥厚性番炎 4.8 $\%$ ，単純性菱縮性鼻炎 $9.2 \%$ ，鼻茸 $7.8 \%$ ，急性副鼻控 炎 $6.4 \%$ ，慢性副鼻䶼炎 $8.5 \%$ ，中隔礬曲症 $3.2 \%$ ，舅

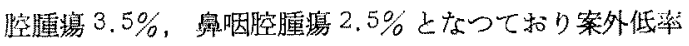
であるが、これは舆覚障害が軽度な場合は患者自身が自 覚していないことがありまたこちらから問診されないと 㖵覚障害を訴えない場合もあるからである。

以上の統計からも鼻副鼻腔疾息中，日常外来で最も頻 般に遭遇するのは慢性副舀腔炎患者にみられる嗅覚障害 である．泉茸は慢性副鼻腔炎に附随して生ずるものであ るから，これも慢性副鼻腔炎によるものと考觉れば一尿 高率になる，単純性萎縮性與炎扰よび急性副鼻腔炎に上 る唤覚障害は䏩述の統計中では，かなり高率ではあるが この二疾患は，日常外来で遭遇することは此較的少な

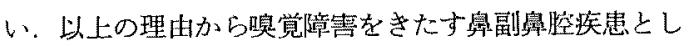

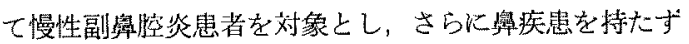
に搝覚障害をきたす，いわ的る神絟性嗅覚障害と称され ているものを刘象とした，さらに少数ではあるが中枢性 搝覚障壱と思われる交通事故による頭部外傷後遗症とし ての嗅覚障害についても検楌した。 
第 1 節 慢性副與控炎と嗅賞障害について

慢性副奥腔炎患者 38 名について喚素ビン检查を施行 した結果 5000 倍稀釈液嗔覚可能で自覚的に嗅覚障害の 訴えのないるの24名で，5000 倍稀䣋液嗅覚不能な嗅覚 障害者と思われる者 14 名であつた，前者の慢性副鼻腔 炎患者で嗅覚障害のない群，後者の慢性副鼻焢炎患者て 喚覚障害のある群に分けて検討した。

1) 慢性副鼻腔炎患者で喚覚障害のない群

被梌者は男子11名，女子13 名の計 24 名である，喚 素液は原液 $2 \mathrm{ml}$ であり模查成樍は表 (17) のごとくで ある、測定值の平均扰よびその $95 \%$ 信頼限界は，
潜 伏㭙間
9.0 秒土 0.9 秒
最大嗅感までの時間
13.8 秒土 3.8 秒
持続 時間
66.4 秒土9.8 秒

である。

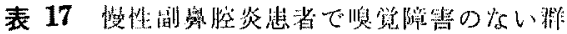
(㟫液 $2 \mathrm{ml}$ )

\begin{tabular}{|c|c|c|c|c|c|c|}
\hline 症例 & 姚: & 年令 & 性 & 潜伏時闑 & \begin{tabular}{|l|} 
最大嗅感ま \\
での時間 \\
\end{tabular} & 持続時間 \\
\hline 1 & 大 谷 & 35 & $\delta$ & 7.0移 & 17 . 0 移 & 49. . 秒 \\
\hline 2 & 諸 江 & 29 & 우 & 9.6 & 17.0 & 39.0 \\
\hline 3 & 濟 藤 & 47 & 우 & 8.0 & 1.0 & 60.0 \\
\hline 4 & 籍 越 & 36 & 우 & 11.0 & 22.0 & 54.6 \\
\hline 5 & 中 村 & 22 & 우 & 13.0 & 18.0 & 49.0 \\
\hline 6 & 諸 野 & 29 & q & 7.3 & 1.0 & 52.6 \\
\hline 7 & 水 政 & 23 & क & 9.6 & 16.3 & 62.3 \\
\hline 8 & 宮田 & 14 & 8 & 7.0 & 20.6 & 102.9 \\
\hline 9 & 大 林 & 30 & $\delta$ & 13.3 & 7.0 & 52.6 \\
\hline 10 & 大塭 & 13 & $\delta$ & 10.0 & 3.0 & 52.3 \\
\hline 11 & 小 間 & 16 & 우 & 5.6 & 3.3 & 43.3 \\
\hline 12 & 川 端 & 17 & 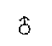 & 8.8 & 17,6 & 109.4 \\
\hline 13 & 波 多 & 14 & 8 & 10.0 & 28.3 & 99.6 \\
\hline 14 & 西 野 & 29 & 우 & 6.0 & 39.3 & 87.6 \\
\hline 15 & 松 田 & 20 & $\delta$ & 8.3 & 13.3 & 58.6 \\
\hline 16 & 緎 11 & 55 & $q$ & 8.6 & 15.8 & 45.4 \\
\hline 17 & 柴 & 18 & 3 & 9.6 & 16.0 & 37.0 \\
\hline 18 & 公 村 & 19 & s & 7.3 & 15.6 & 37.9 \\
\hline 19 & 㟊本 & 25 & $\delta$ & 13.0 & 14.3 & 63.6 \\
\hline 20 & 斗非 (it) & 16 & $\delta$ & 7.1 & 8.3 & 79.3 \\
\hline 21 & 科 谷 & 17 & 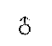 & 10.6 & 4.6 & 79.2 \\
\hline 22 & 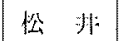 & 20 & 웅 & 7.0 & 5.3 & 85.9 \\
\hline 23 & 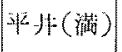 & 17 & q & 12.3 & 8.0 & 84.6 \\
\hline 24 & 高 橋 & 18 & 우 & 7.3 & 19.0 & 108.0 \\
\hline & $95 \%$ 墂限 & & & $\begin{array}{c}9.0 \\
9.0 \pm 0.9\end{array}$ & $\begin{array}{c}13.8 \\
13.8 \pm 3.8\end{array}$ & $\begin{array}{c}66.4 \\
66.4 \pm 9.8\end{array}$ \\
\hline
\end{tabular}

一般外来正常者の成績（表 4)に此較して，潜代時間，

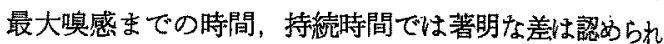
なかつた。

2) 慢性副鼻腔炎患者で嗅覚障害のある群

被検者は男子 6 名，女子 8 名の計 14 名である。摬郜 液は原液 $2 \mathrm{ml}$ であり検查成績は表（18）のごとくであ る、測定値の平绚招よびその $95 \%$ 信頼限界は
潜 伏 時 間
15.0 秒士 3.4 秒
最大嗅感までの時間
12.1 秒士 3.1 秒
持 続 時 閐
48.0 秒土 6.1 秒

である。

一般外来正常者の成績に比較して，潜伏時間は約 7 秒 延長し 持続時間は約 21 秒短縮した，最大嗅感亡での時 間には著明な差は認められなからた，慢性副鼻腔炎で照 覚障害のない群と比較するに潜伏時間では6秒延長し，

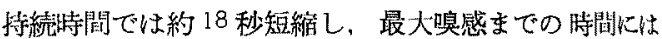
著明な差佂みられなからた。

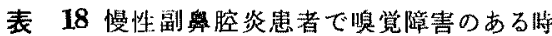
(原液 $2 \mathrm{ml}$ )

\begin{tabular}{|c|c|c|c|c|c|c|}
\hline $\begin{array}{l}\text { 定 } \\
\text { 例 }\end{array}$ & 姓 & 年性 & 潜伏時間 & $\begin{array}{l}\text { 最大唲感ま } \\
\text { での時間 }\end{array}$ & 持続時間 & 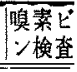 \\
\hline 1 & 壁下 & 168 & 21.0秒 & 1.0秒 & 38 .6秒 & $1 \times 100$ \\
\hline 2 & 室谷 & $20 \mid$ P & 10.3 & 12.3 & 58.9 & $\times 1000$ \\
\hline 3 & 卜部 & 53 우 & 19.0 & 16.6 & 48.3 & 原(-) \\
\hline 4 & 島村 & 20 우 & 8.0 & 12.0 & 47.6 & $\times 500$ \\
\hline 5 & 玉木 & 15 今 & 7.6 & 13.3 & 46.3 & $\times 1000$ \\
\hline 6 & 維谷 & 13 क & 10.3 & 7.6 & 44.9 & $\times 1000$ \\
\hline 7 & 田本 & 22 \% & 16.6 & 8.6 & 54.6 & 原 $( \pm)$ \\
\hline 8 & 谷内 & $21 \%$ & & 15.0 & 49.6 & 愿 \\
\hline 9 & 步内 & $22 \%$ & 14.0 & 7.0 & 28.6 & $\times 500$ \\
\hline 10 & 中川 & 148 & 15.3 & 14.0 & 28.3 & 源( \\
\hline 11 & 柳田 & $17 \mid \hat{0}$ & 6.6 & 11.0 & 55.3 & $\times 1000$ \\
\hline 12 & 番匠. & 20 के & 16.0 & 10.0 & 49.0 & $\times 1000$ \\
\hline 13 & 出島 & 47 है & 25.9 & 20.3 & 63.6 & $\times 100$ \\
\hline 14 & HII & 189 & 16.3 & 21.8 & 59.4 & $\times 100$ \\
\hline & & 均 & $\begin{array}{r}15 . \\
0.0 \pm\end{array}$ & $\begin{array}{r}12.1 \\
12.1+3\end{array}$ & $\begin{array}{r}48.0 \\
48\end{array}$ & \\
\hline
\end{tabular}

さて柣は先に潜伏時間について，軽度嗅覚減退者と唤 覚正常渚とでは原液による臨別は困難であると述へで括 るが，持続封間，最大嗅感までの㭙間に関してはいかかが なものか，1000 倍稀橎液嗅覚可能な 6 名についてさら に検討した.

すなわち6名の平均值およびその $95 \%$ 信頼限界は次 のとおりである. 

潜 伏時 間
11.2 秒士4.3秒
最大嗅感玉での时㒎
12.7 秒土5.1 秒

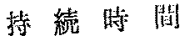
52.3 秒上 6.7 秒

である、潜伏時間，最大嗅感までの時間では著明な善が なく，持続特間で 17 秒の短縮が認められた。

3）慢性副蕃腔炎患者で嗅覚障害のないものにお

ける鮕素液の量和よび澧度についての再検討

第 1 項に叔いて一般正常者と唤覚障害のない慢性副鼻

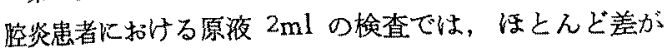

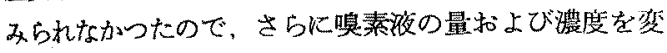
点て检討した。

(1) 10 位稀釈 $2 \mathrm{ml}$

被検者は男子 13 名，女子5 名の計 18 名であり，検查 成績は表（19）のごとくである，測定值の平均朊よびそ の $95 \%$ 信頼限界は

$\begin{array}{lr}\text { 潜 伏 時 間 } & 9.7 \text { 秒さ1.1 秒 } \\ \text { 最大喚感ざの時間 } & 12.5 \text { 秒士3.6 秒 } \\ \text { 持 続 時 間 } & 46.8 \text { 秒 } 18.2 \text { 秒 }\end{array}$
である。

表 19 摱性㔊奥腔炎患者で嗅觉障害のない群 (10培稀积液 $2 \mathrm{ml}$ )

\begin{tabular}{|c|c|c|c|c|c|c|}
\hline 症例 & 姓 & 年令 & 珄 & 潜伏時間 & $\mid$\begin{tabular}{|l|}
$\mid$ 最大嗅感ま \\
での時間
\end{tabular} & 持続時間 \\
\hline 1 & 齊藤 & 47 & 우 & 10.6秒 & 2.0秒 & 23.0梨 \\
\hline 2 & 霜越 & 36 & $q$ & 10.6 & 13.0 & 37.0 \\
\hline 3 & 波多 & 14 & $\delta$ & 10.6 & 17.0 & 61.0 \\
\hline 4 & 川1端 & 17 & $\delta$ & 7.5 & 29.3 & 69.3 \\
\hline 5 & 西野 & 29 & 우 & 8.0 & 23.6 & 54.9 \\
\hline 6 & 松本 & 14 & $\delta$ & 8.0 & 6.6 & 52.2 \\
\hline 7 & 松田 & 16 & $\hat{s}$ & 11.3 & 13.5 & 31.2 \\
\hline 8 & 山田 & 18 & 우 & 9.5 & 7.0 & 23.3 \\
\hline 9 & 柴野 & 18 & 8 & 9.3 & 15.0 & 31.6 \\
\hline 10 & 元村 & 19 & $\delta$ & 10.5 & 12.5 & 24.1 \\
\hline 11 & 池本 & 25 & t & 8.1 & 8.6 & 32.2 \\
\hline 12 & 中田 & 30 & $\delta$ & 9.6 & 10.0 & 47.0 \\
\hline 13 & 平井 & 16 & $\hat{b}$ & 6.0 & 7.6 & 54.9 \\
\hline 14 & 神谷 & 17 & $\delta$ & 10.3 & 3.0 & 60.3 \\
\hline 15 & 上野 & 16 & $\hat{\delta}$ & 9.1 & 10.0 & 47.5 \\
\hline 16 & 松井 & 20 & 웅 & 7.3 & 8.3 & 54.9 \\
\hline 17 & 友杉 & 45 & $\delta$ & 13.0 & 22.5 & 69.1 \\
\hline 18 & 田中 & 52 & $\delta$ & 15.6 & 15.0 & 69.6 \\
\hline & $\begin{array}{l}\text { 平㘬 } \\
95 \% 1\end{array}$ & & & $\begin{array}{r}9.7 \\
9.7 \pm 1 .\end{array}$ & $\begin{array}{c}12.5 \\
12.5 \pm 3.6\end{array}$ & $\begin{array}{r}46.8 \\
46.8 \pm 8 .\end{array}$ \\
\hline
\end{tabular}

(2) 100 倍稀瀵 $2 \mathrm{ml}$

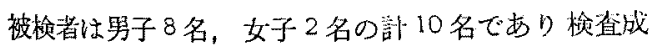

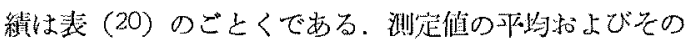
$95 \%$ 信頼限界仙

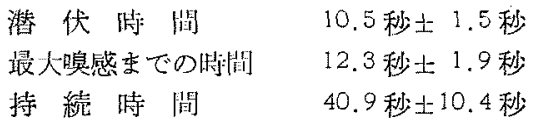
である。

表 20 慢性副舜腔炎䓡者で嗅覚障害のない群 (100 倍稀釈 $2 \mathrm{ml}$ )

\begin{tabular}{|c|c|c|c|c|c|c|}
\hline 漩例 & 姓 & 年令 & 性 & 潜伏時閥 & \begin{tabular}{|l|} 
最大䚐感 \\
での㭙間 \\
\end{tabular} & 持紴時間 \\
\hline 1 & 松田 & 20 & $\delta$ & 13.0秒 & 15.3秒 & 71.3 秒 \\
\hline 2 & 織田 & 55 & q & 8.3 & 15.5 & 32.5 \\
\hline 3 & 柴野 & 18 & $\hat{\delta}$ & 10.6 & 14.6 & 35.7 \\
\hline 4 & 元村 & 19 & $\delta$ & 11.8 & 14.6 & 35.9 \\
\hline 5 & 池本 & 25 & $\hat{\delta}$ & 12.3 & 11.3 & 38.6 \\
\hline 6 & 中田 & 30 & 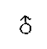 & 13.3 & 12.0 & 28.3 \\
\hline 7 & 山口 & 18 & 우 & 10.0 & 8.6 & 61.6 \\
\hline 8 & 平形 & 16 & $\beta$ & 7.3 & 9.3 & 46.3 \\
\hline 9 & 上野 & 17 & $\hat{\beta}$ & 9.6 & 10.3 & 29.3 \\
\hline 10 & 神谷 & 17 & $\delta$ & 9.0 & 12.1 & 30.1 \\
\hline & $50 \%$ & 值 & & $\begin{array}{c}10.5 \\
10.5 \pm 1.5\end{array}$ & $\begin{array}{c}12.3 \\
12.3 \pm 1.9\end{array}$ & $\begin{array}{c}40.9 \\
10.9 \pm 10.4\end{array}$ \\
\hline
\end{tabular}

(3) 10 倍稀积 $5 \mathrm{ml}$

被検者は男子11名，女子 5 名の計 16 名であり检查成

表 21 僈性副鼻腔炎患者で嗅覚障害のない群 (10 倍稀粎液 $5 \mathrm{ml}$ )

\begin{tabular}{|c|c|c|c|c|c|c|}
\hline 症例 & 姓: & 年令 & 性 & 潜伏時間 & \begin{tabular}{|l|} 
最大嗅感ま \\
での时間
\end{tabular} & 持綘洔間 \\
\hline 1 & 正本 & 15 & $\delta$ & 7.6 利 & 17.6秒 & 97.9秒 \\
\hline 2 & 川嘖 & 17 & $\hat{\delta}$ & 9.3 & 21.3 & 117.6 \\
\hline 3 & 设多 & 14 & 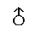 & 11.8 & 21.0 & 119.3 \\
\hline 4 & 踏谷 & 13 & $\delta$ & 6.6 & 26.8 & 83.4 \\
\hline 5 & 西野 & 29 & 우 & 6.3 & 19.3 & 76.6 \\
\hline 6 & 松田 & 20 & 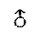 & 13.3 & 21.6 & 57.9 \\
\hline 7 & 織田 & 55 & 우 & 9.0 & 28.3 & 54.9 \\
\hline 8 & H10 & 18 & ? & 8.8 & 11.6 & 41.9 \\
\hline 9 & 柴野 & 18 & $\delta$ & 11.0 & 12.6 & 57.9 \\
\hline 10 & 元村 & 19 & $\hat{\delta}$ & 7.3 & 22.6 & 44.2 \\
\hline 11 & 池本 & 25 & 8 & 9.3 & 20.6 & 53.6 \\
\hline 12 & 平井 & 16 & 3 & 6.3 & 3.3 & 41.0 \\
\hline 13 & 科谷 & 17 & $\$$ & 12.6 & 8.6 & 63.2 \\
\hline 14 & 上政 & 17 & 古 & 8.3 & 8.0 & 56.3 \\
\hline 15 & 松半 & 20 & 웅 & 8.6 & 3.6 & 73.6 \\
\hline 16 & 越咞 & 19 & q & 10.3 & 4.3 & 41.6 \\
\hline & 50 & 湢 & & $\begin{array}{c}9.1 \\
9.1 \pm 1\end{array}$ & 15.7 & $\begin{array}{c}67.5 \\
5 \pm 13.6\end{array}$ \\
\hline
\end{tabular}


樍は斐（21）のごとくである，湘定值の平均执よびその 95\%信頼限界は
潜伏 時 間
9.1 秒士 1.2 秒
最大唤感胥での时間
15.7 秒土 4.4 秒
持 続 時 間
67.5 秒土 13.6 秒 である。

(4) 100 倍稀䣋 $5 \mathrm{ml}$

被検者は男子 8 名，女子 2 名の計 10 名であり検査成 績は表（22）のごとくである，測定值の平均枕よびその $95 \%$ 信頼限界は

$\begin{array}{ll}\text { 潜 伏 時 間 } & 11.1 \text { 秒士 } 1.9 \text { 秒 } \\ \text { 最大嗅感までの時間 } & 13.9 \text { 秒士 } 5.3 \text { 秒 } \\ \text { 持 続 時 間 } & 60.6 \text { 秒士 } 11.7 \text { 秒 }\end{array}$ である。

表 22 漫性副奥腔炎患者で嗅覚障害のない群 (100 倍稀秋 $5 \mathrm{ml}$ )

\begin{tabular}{|c|c|c|c|c|c|c|}
\hline 症例 & 姓 & 年令 & 性 & 潜伏時間 & $\begin{array}{l}\text { 最大䶎感ま } \\
\text { での時間 }\end{array}$ & 持経時間 \\
\hline 1 & 松田 & 20 & $\delta$ & 15.3秒 & 14.3秒 & 61.3 秒 \\
\hline 2 & 織田 & 55 & 우 & 12.0 & 30.6 & 50.9 \\
\hline 3 & 柴野 & 18 & $\delta$ & 11.3 & 20.8 & 60.1 \\
\hline 4 & 池本 & 25 & $\delta$ & 9.3 & 14.6 & 47.2 \\
\hline 5 & 山口 & 18 & 우 & 14.2 & 7.0 & 44.6 \\
\hline 6 & 武田 & 15 & $\delta$ & 12.6 & 15.6 & 73.6 \\
\hline 7 & 平并 & 16 & $\delta$ & 7.3 & 6.3 & 50.9 \\
\hline 8 & 神谷 & 17 & $\delta$ & 12.0 & 16.6 & 93.2 \\
\hline 9 & 上野 & 17 & $\delta$ & 8.0 & 8.0 & 45.6 \\
\hline 10 & 松井 & 20 & $\delta$ & 9.0 & 6.0 & 78.6 \\
\hline \multicolumn{4}{|c|}{$\begin{array}{l}\text { 平均值 } \\
95 \% \text { 信哏 }\end{array}$} & $\begin{array}{c}11.1 \\
11.1 \pm 1.9\end{array}$ & $\begin{array}{r}13.9 \\
13.9 \pm 5\end{array}$ & $\begin{array}{r}60.6 \\
60.6+11\end{array}$ \\
\hline
\end{tabular}

(5) 10 倍稀釈 $10 \mathrm{ml}$

被検者は男子6名，女子4名の計 10 名であり検査成 續は表（23）のごとくである，測定值の平均和よびその $95 \%$ 信頼限界は

$\begin{array}{ll}\text { 潜 伏 時 間 } & 10.7 \text { 秒士 } 1.0 \text { 秒 } \\ \text { 最大㬇感までの時閆 } & 14.3 \text { 秒士 } 2.3 \text { 秒 } \\ \text { 持 続 時 間 } & 79.0 \text { 秒士15.5 秒 }\end{array}$
である。

(6) 100 倍稀䣋 $10 \mathrm{ml}$

被検者は男子8名，女子 2 名の計 10 名であり検直成 績は表 (24) のごとくである．測定値の平均怙よびその $95 \%$ 信頼限界仙

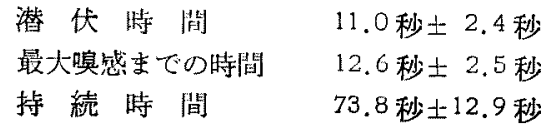

表 23 慢性副㭧腔炎患者で嗅覚障害のない群 (10 倍稀粎 $10 \mathrm{ml}$ )

\begin{tabular}{|c|c|c|c|c|c|c|}
\hline 症例 & 姓 & 年命 & 性 & 潜伏時間 & $\begin{array}{l}\text { 最大倹感ま } \\
\text { での時間 }\end{array}$ & 持続時間 \\
\hline 1 & 松田 & 20 & $\hat{\delta}$ & 10.0秒 & 17.0 秒 & 112,0 秒 \\
\hline 2 & 織田 & 55 & 우 & 11.8 & 14.0 & 50,8 \\
\hline 3 & 柴野 & 18 & $\delta$ & 10.6 & 13.6 & 95,2 \\
\hline 4 & 元村 & 19 & है & 10.0 & 18.0 & 80.3 \\
\hline 5 & 池本 & 25 & $\delta$ & 8.0 & 11.3 & 43.3 \\
\hline 6 & 中田 & 30 & $\delta$ & 10.3 & 12.0 & 103.0 \\
\hline 7 & 山口 & 18 & 우 & 12.6 & 9.3 & 66.3 \\
\hline 8 & 水木 & 28 & 우 & 11.9 & 14.6 & 74.6 \\
\hline 9 & 沢井 & 31 & $\delta$ & 10.2 & 20.0 & 79.2 \\
\hline 10 & 今川 & 20 & 우 & 12.0 & 13.4 & 86.0 \\
\hline & 均 & 値 & & $\begin{array}{c}10.7 \\
10.7 \pm 1.0\end{array}$ & $\begin{array}{r}14.3 \\
143+2\end{array}$ & $\begin{array}{r}79.0 \\
.0+15.5\end{array}$ \\
\hline
\end{tabular}

表 24 慢性副楀腔炎患者で嗅覚障害のない群 (100 倍稀积液 $10 \mathrm{ml}$ )

\begin{tabular}{|c|c|c|c|c|c|c|}
\hline 证例 & 姓 & 年令 & 性 & 潜伏時間 & 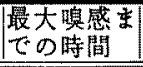 & 持続時間 \\
\hline 1 & 松田 & 20 & $\delta$ & 8.6 秒 & 12.6 科 & $110.9 y^{2}$ \\
\hline 2 & 織田 & 55 & 9 & 10.0 & 15.3 & 51,9 \\
\hline 3 & 柴野 & 18 & $\hat{\delta}$ & 9.0 & 20.0 & 87,3 \\
\hline 4 & 元村 & 19 & $\hat{\delta}$ & 11.3 & 9.6 & 60.9 \\
\hline 5 & 池本 & 25 & 8 & 9.1 & 11.0 & 81.1 \\
\hline 6 & 中田 & 30 & $\hat{\partial}$ & 11.6 & 9.6 & 59.7 \\
\hline 7 & 山口 & 18 & 우 & 19.3 & 12.3 & 58.6 \\
\hline 8 & 武田 & 15 & $\hat{\delta}$ & 12.0 & 16.0 & 88.5 \\
\hline 9 & 平井 & 16 & $\hat{o}$ & 10.5 & 9.0 & 70.0 \\
\hline 10 & 上野 & 17 & $\delta$ & 9.1 & 11.2 & 69.4 \\
\hline & 均 & 值 & & $\begin{array}{c}11.0 \\
11.0 \pm 2.4\end{array}$ & $\begin{array}{r}12.6 \\
12.6 \pm 2 .\end{array}$ & $\begin{array}{r}73,8 \\
8 \pm 12.9\end{array}$ \\
\hline
\end{tabular}

である。

以上の成績を嗅覚正常者の 成績（表 11）と比蔪する と，潜伏時間，最大嗅感までの時間ではいずれる著明な 差は認められず，持続時間に括いてのみかなりの短維が 認められた。

第 2 節 いわゆる神経性唤覚障害について

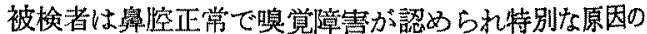
見当らないるので男子 3 名，女子9名の計 12 名であり， 嗔素液は原液 $2 \mathrm{ml}$ である，検查成績は表（25）のごと くで測定值の平均和よびその $95 \%$ 信頼限界は
潜 伏 時 間
18.5 秒士 5.8 秒
最大㖟感までの時間
8.8 秒士 4.0 秒
持 続 時 間 
である。

一般正常者の原液 $2 \mathrm{ml}$ の成續之比較して潜伏時閪て は約 11 秒の延長，最大喚感までの時間では約 4 秒，持

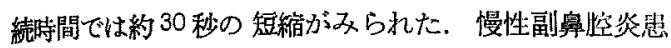
者で嗅覚障害のある者の原液 $2 \mathrm{ml}$ の成績と比較して潜 伏洔間では約 3 秒の延長，最大嗅感までの時間では約 3 秒，持続侍間では約 10 秒の短縮がみられた。

表 25 神経性嗅覚障害者（原液 $2 \mathrm{ml}$ )

\begin{tabular}{|c|c|c|c|c|c|}
\hline 症 & 姓 年|性| & 潜伏時間 & 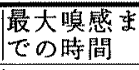 & 持紶時間 & 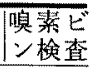 \\
\hline 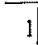 & 河原 $|51|$ \% & 29 .3秒 & 7.0 秒 & \multicolumn{2}{|c|}{42.3 秘原 } \\
\hline & 中川 $24 \delta$ & 21.6 & 3.0 & 11.3 & 原 $( \pm)$ \\
\hline & 楜元 36 . & 13.0 & 11.5 & 40.8 & 原 $( \pm)$ \\
\hline 4 & 酒井 189 & 39.0 & 15.3 & 81.6 & 原 \\
\hline & 石川 $53 \%$ & 22.0 & 6.3 & 24.6 & 原( $(-)$ \\
\hline & 森 528 & 11.6 & 11.0 & 27.0 & $\times 100$ \\
\hline & 中野 54 古 & 17.6 & 17.6 & 54.6 & $\times 100$ \\
\hline 8 & 洪中 32.9 & 18.3 & 6.3 & 53.9 & $\times 10$ \\
\hline & 伴 $18 \mid$ 号 & 19.6 & 2.5 & 26.1 & 原(一) \\
\hline 10 & 横山 39 | & 15.6 & 20.3 & 52.6 & $\times 10$ \\
\hline 11 & 桶田 53 . & 9.3 & 3.0 & 18.3 & $\times 10$ \\
\hline 12 & 久田 50 \% & 5.1 & 2.0 & 17.3 & $\times 500$ \\
\hline & 更 & $\begin{array}{l}18,5 \\
.5 \pm 5 .\end{array}$ & $\begin{array}{r}8.8 \\
8.8 \pm 4 .\end{array}$ & $\begin{array}{r}37.5 \\
5+130\end{array}$ & \\
\hline
\end{tabular}

第 3 節 頭部外傷後遣症による嗅覚障害について

最近，神経性嗅覚障害のらちの中枢泩嗅覚害之思加れ る交通事故による頚部外傷後の嗅覚障害 2 症例を得たの で娭罸した。

[症例 1) 松田 21 才文于

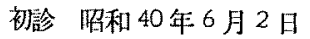

39 年 2 月，交通事故にあい右後頭部を打撲，意識消 失し頭蓋底骨折の診断をうけ某病院に 2 ケ月半入院，意 識障害は約 10 日間続いた，退院後懙覚障害に気付いた。

鼻腔所見 両側喚裂中鼻道はきれいに開放し，分速 物，鼻腔粘膜の腫脹，その他の病的所見は認められな い.

(症例 2) 竹沢 23 才男子

初診㫟和 40 年 8 月 30 日

40 年 5 月，交通事故で䫓部を打撲し 喕蓋底岁折の診 断で某病院比約1ヶ月入院，治療をらけた．受稘後嗅覚 減退を来たし日常生活では，かなり強いに挌いしか感じ な⿻.

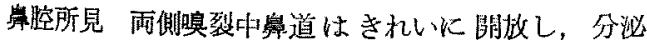
物，鼻腔粘膜の腫脹などは認められない。

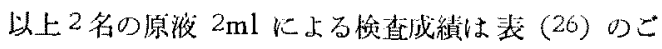
とくであり平均値は

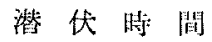

11.3 秒

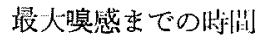

3.7 秒

持続 時间

15.1 秒

である.

表 26 頭部外儌後の搝觉障害者（原液 $2 \mathrm{ml}$ )

\begin{tabular}{|c|c|c|c|c|c|c|c|}
\hline 定例 & 姓 & $\begin{array}{l}\text { 年 } \\
\text { 令 } \\
\end{array}$ & 性 & 潜伏時間 & \begin{tabular}{|l} 
最大嗅感里 \\
での時間 \\
\end{tabular} & 持紩㭙間 & \begin{tabular}{|l} 
噢票七 \\
ソ検查
\end{tabular} \\
\hline 1 & 松田 & 21 & $\phi$ & 11.1 秒 & 4.3秒 & 16.3 秒 & $\times 10$ \\
\hline 2 & 竹沢 & 23 & $\S$ & 11.5 & 3.1 & 13.9 & 原 \\
\hline & & & & 11.3 & 3.7 & 15.1 & \\
\hline
\end{tabular}

一般正常者と比較して潜伏㭙間では約 3 秒延長し最大 嗅感むでの持間は約 9 秒，持緦時間では約 54 秒短縮し た。また神経性嗅覚障害と此較して潜伏時間では約 7 秒，最大嗅感までの時闑では約 5 秒，持続時間では約 22 秒短縮した。

第 4 節 考按ならびに小括

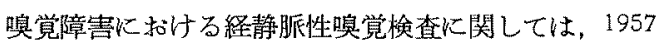
年工藤 21) は $5 \mathrm{mg} 1 \mathrm{ml}$ のアリナミン液を20 倍に稀釈

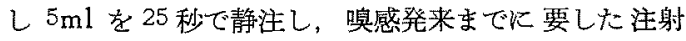
量で潜伏時間を表現した。そして正常者，慢性副奥腔炎

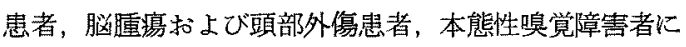
ついて实験を行ない，正常者に沏いて瑱感発来までの注

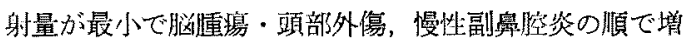
加すると述へた，1957年大沉，南条らはアリナミン 10 $\mathrm{mg} 2 \mathrm{ml}$ を静注して正常者，唤覚障蛪者の潜伏時間を 比校し，喚覚愃慧の治嬑にもアリナミン静注を行ない潜 代时間と治療刘果について報告した。また1960年に甫 原らは番性嗅覚, 経静脈性嗅覚について多くの報告を行 ない検查法の改良，それに上る嗅覚障害の病型の分類な どを行なつた。

経静脈性唤觉検査に䊀ける持続時間の意義と重要性に ついては，1963年神尾が初めて報告した，氏はフリナミ ン $10 \mathrm{mg} 2 \mathrm{mI}$ を20 秒で静注し注㶲開始より㖟感発来ま

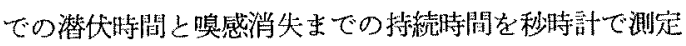

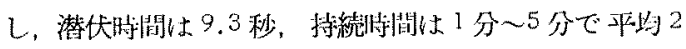
分50秒と報告している。

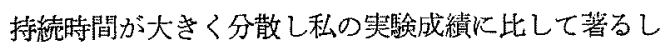

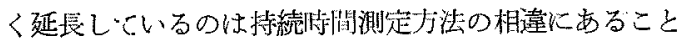
はすでに述べたところである。

さて，嗅感曲楾記録装㯰の臨林的応用として慢性副㝴 


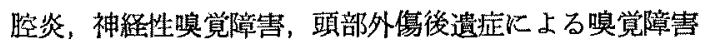
を対象として検查を行なつた。これらの椧査成績から潜 伏時間，最大嗅感妾での時間，持続時間の三項について 5\%以下の危除率で推計学的に検討した.

潜伏時間汇関しては

（1）嗅覚正常者と慢性副與腔炎患者で唤覚障害のない 者との間, 有意の美を認め難い.

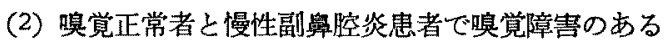
者との間, 有意の差を認める.

(3) 喚覚正常者と神経性嗅覚障害者との間，有意の差 を認める。

（4）慢性副鼻腔炎患者で嗅覚障害のある者とない者と の間，有意の差を認める。

(5) 慢性副鼻腔炎患者で嗅覚障害のある者と神経性筃 覚障害者との間. 有意の差を認め難い。

最大残感までの時間汇関しては

全ての組み合せにおいて有意の差を認め難い，

持続時間に関しては

(1) 嗅覚正常者と慢性副鼻腔炎患者で嗅覚障害のない 者との間，有意の差を認め難い。

(2) 嗅覚正常者と慢性副鼻腔炎患者で嗅覚障害のある 者との間，有意の差を認める。

(3) 嗅覚正常者之神経性嗅覚障害者との間，有意の羑 を認める.

（4）慢性副鼻腔炎患者で嗅覚障害のない者とある者と の間，有意の差を認める。

(5) 慢性副鼻腔炎患者で喚覚障害のあるものと神経性 喚覚障害者との間, 有意の差があるとは認め難い.

以上の检定結果より，慢性副鼾腔炎患者で嗅覚障害の ある者と神経性嗅覚障害者との間では，原液 $2 \mathrm{ml}$ を嗅 素液として使用した場合には潜伏時間，最大嗅感までの 時間，持続時間ともに有意の差は認められず，嗅感曲線 からだけでは両者の爁別は困難である.すなわち両者と むに潜伏時間は延長し，持続時間は短縮する傾向を示し た．この傾向は実験的嗅覚障害の嗅上皮性嗅覚障害に相 当するすのである。

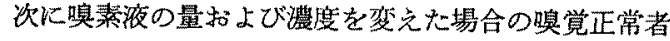
と慢性副奥腔炎患者で嗅覚障害のない者の成績について 有意性の検定を行なつた。

（1）㧝素液の量および濃度を変えてい潜伏時間および 最大嗅感むでの時間はともに有意の差が認められなかつ た.

（2）持続時間に和いては，10 倍稀釈 $10 \mathrm{ml}$ および 100
倍稀釈 $10 \mathrm{ml}$ を使用した場合には有意の差が認められ た.

すなわち嗅素液として $2 \mathrm{ml} ， 5 \mathrm{ml}$ を使用した場合化 は，鮕覚正常者と慢性副鼻腔炎患者で鮕覚障害のない者 との間に嗅感曲線上有意の差を認め難いが，10倍稀积

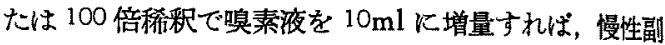
鼻腔炎患者では明らか炕持続時間が短縮することがわか つた．これは実験的鮕覚障害についての実験結果汇照合 して動腔内ことに鮕裂の资症性腫脹などによる軽度の通 過障害のためと考えられる。

次に前章の実験的嗅覚障害時之嗅覚障贵のある慢性副 鼻腔炎患者括よび神経性嗅覚障害者との間の有意性の检 定を行なつた。

潜伏時間では

（1）慢性副鼻腔炎患者と嗅裂閉鎖時との間，有意の差 を認める。

（2）慢性副鼻腔炎患者上 麻酔後 10 倍稀积液墁賞可能 までに回復した時との間，有意の差を認め難い。

（3）慢性副鼻腔炎患者之麻酥後 500 倍稀釈液嗅覚可能 までに回復した時との間，有意の差を認める。

（4）神経性嗅覚障害者と嗅裂閉鎖時との間，有意の差 を認める。

（5）神経性鮕覚障害者上林酔後 10 倍稀釈液嗅覚可能 までに 回復した時との間，有意の差があるとは認め難 W.

（6）神経性嗅覚障害者之麻酔後 500 倍稀釈液嗅覚可能 までに回復した時との間，有意の差を認める。

最大喚感までの時間では

全ての組み合せで有意の差を認め難い，

持続特間では

（1）慢性副悬腔炎患者と喚裂閉鎖時との間，有意の美 を認め難い。

（2）慢性副鼻腔炎患者 と麻西杂後 10 倍稀釉液嗅覚可能 時との間，有意の差を認める。

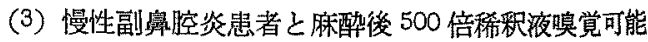
時との間，有意の差を認め難い，

（4）神経性喚覚障害者之哭裂閉鎖時との間，有意の差 を認める。

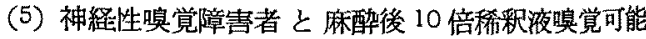
時との間. 有意の差を認め難い。

（6）神経性嗅覚障察者と麻酥後 500 倍稀釈夜嗅覚可能 時との間，有意の差を認め難い。

以上の检定結果より神経性嗅覚障害と乎ばれている。 
の法，主として嗅上皮の機能低下による㭡覚障害と考兄 られ，慢珄副鼻腔炎時の嗅覚障害は単なる鼠腔形態の異 常，主として嗅裂の通過障害だけによるものでなく续上 皮の機能低下による要素が多分に含まれているものと推 定される。

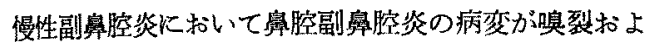
び瑱上皮に和よぶことは充分予想されることであり， 1958 年高㭻 22) らは口腔鼻腔㸶頭似直接死因を持たない、 41 例の成人屍体火ついて 観察し，嗅裂部の 接着 (32.9 \%)，瘜着 (21.9\%) がみられたと報告し殊に上記の変 化恃上鼻甲介部著るしく，この部に炎症が波及すると 上皮涂脱，細胞浸潤，空㩐部での分汹物㮃溜等が起り， さらにこれらが機質化し上皮の重層扁平上皮化の原因々 なると述べている。 また 1961 年中原 ${ }^{23)}$ は組䌬学的検索 から慢性副鼾腔炎の際に発現する嗅覚障害之嗅粘膜及び 嗅球の組織学的病変との間にははぼ平行関係がうがが れると述へている。

以上の点より慢性副威腔炎に伴う唤覚障害と神経性喚 覚障害はともに嗅上皮性の要因を持つことから経静脈性

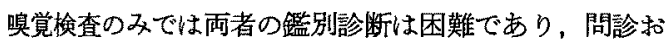
よび鼻腔所見を参考としなければならないと考えられ る。

頭部外傷後遺症による嗅覚障害はわずか 2 名のため統 計的考察は行なわなからたが，潜伏時間の延長，最大搝 感をでの時間および持綕時間の短縮がみられたが特に持 綕侍間の著明な短緶が特徽的であつた。

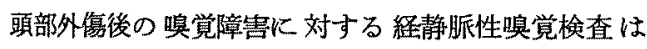
1957 年工藤の 報告の中にみられ，潜仗時間は 4.5 秒 14.0 秒で平均 9.0 秒と述へている。 また 1963 年，神尾 は外傷生嗅覚障害者 3 名について全く嗅感を生じなかつ たと報告しているが外傷部位は不明である。また1964年 Guttih 24) は頭部外傷後，嗅禾の損傷断裂に上り㖵覚脱 失を来たすと述べている。

以上の結果を小括すれば

1) 原花 $2 \mathrm{ml}$ を嗅素液として使用した場合には，嗅覚 正常者と嗅覚障害のない慢性副嶨腔炎患者との間には检 查上有意の差は認められない，㖵覚障害のある慢性副楀 腔炎患者之神経性嗅覚障害者之の間にも同じく有意の差 が認められず，両者とも潜伏時間は延長し持続時間は短 縮する。

2）咱素液を10 倍 100 倍稀釈でそれぞれ $10 \mathrm{ml}$ に增量 した場合には，鮕覚正常者と慢性副鼻腔炎患者で鮕覚障 害を自覚せざ，フリナミン嗅素ビン検査でも正常値を示
すものとの閒で，持綕時間に有意の差を認め副悬腔炎患 者では短縮する．このことは鼻腔内に形態異常即ち䐜烈 の軽度の通過障害をきたしたためのものであろうと推測 される。

3) いわゆる神経性嗅覚障害といわれるものは嗅上皮 性瑱覚障害であるうと考えられる.

4) 慢性副鼻腔炎にみられる嗅覚障害は，嗅裂の通過 障害による要因の他に暞上皮の機能低下が重要な要因と なつていると推定される。

5) 頭部外傷後遗症による喂覚障害は最大喚感までの 時間呿よび持続時間が短縮し, 特に持続時間の短縮が著 明な特異な型を示した。これは中枢性嗅覚障害の一つの 型をあらわするのと思われる。

\section{第 5 章 結 論}

徉来の経静脈性嗅覚検查では潜伏時間，持続時間の測 定に秒時計を用いてきたが，この方法では嗅感覚の消長 を終始一つのものとして観察，検討することは图難であ り，また被検者の呼吸法る一定せず測定值の分散が大と なり臨床検查法としてはな持満足な結果は得られなから た. 上述の検查法の不備を改善し嗅感の推移を握力の变 化により電気的変化として記録し，嗅感曲線として表現 させることを考案し，この嗅感曲線記録装置を使用して 実験を行い次の結果を得た。

(1) 㖵覚正常者においては, 持続時間は著者の方法 でるかなりの分散がみられる

最大嗅感までの時間は嗅素液の量および濃度を变化さ せても 15 秒以内で大体 12 秒前後であり，有意の差は認 められなからた。

持続時間は同濃度で注射鮕素液量を增量すれば延長す るが，延長の比率は增量の比率以下である.

同じ注射嗅素液量で濃度を10 倍 100 倍に稀释すれば 持続時間は短縮するが，短縮の比率は稀积倍数の比率以 下である。

（2）実験的嗅覚障害について

呼吸性鮕覚障害（鮕裂閉鎖時で 500 倍稀积液嗅覚可能 時)では潜伏時間は正常者と変らないが，持続時間は短 菀する.

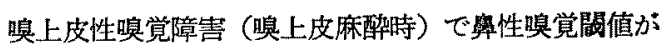
低下するとその障害の程度に比例して，潜伏時間は延辰 し, 持繞時間は短縮する。

鼻性㖵覚閶值が同じ程度まで低下した，乎吸性㖵覚障 害群と嗅上皮性喚覚障害群とを比較すると，潜伏時間で は搝上皮性嗅覚障害群に有意の延長を認めるが，持続時 
間では有意の差が認めら狆なかつつた。

以上の点より潜伏時問は嗅覚障害の原因に，持綕㭙間

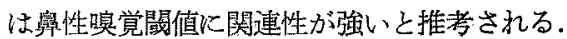

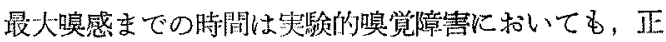

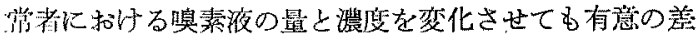
が認められず，最大嗅感までの㭙䦌は嗅上皮より，さら に高次の中枢支配をらけているのではなかららかと推測 むれる。

(3) 臨床的応用

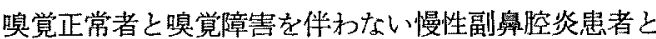
の間には，潜伏時閒最大嗅感までの時間，持続時間に有 意の差が䛱められない。

嗅覚障害を伴つた慢性副窈腔炎患者之神経性嗅覚障害 皆との間には有意の差が認められないが雨者とわ潜伙时 間の延長および持結時間の短縮をみとめる。

いわゆる神絽泩嗼覚障㕩と呼ばれるるのは，复上皮性 嗅覚障慧と推定される.

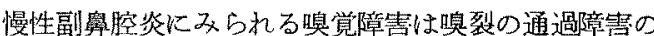
他に殠上皮の機能低下が重要な要因上考えられる。

頭部外傷後遗症による嗅覚障害はむ潜伏時間に大きな変 化なく，持䜌時間が極端な短縮を示し，これは中枢性喚

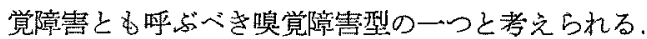

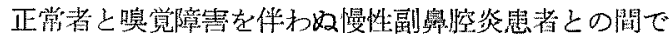

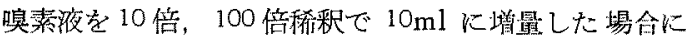

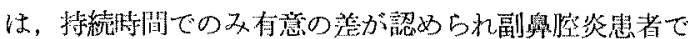

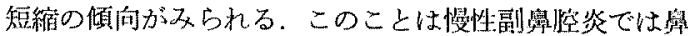
腔粘膜の腫脤などによる嗅裂の軽度の通過障革をさたす ためと推测される。

\section{主 要 文 献}

1) Zwaardemaker, H.: Die Physiologie des Geruchs, Leipzig, W. Engelmann 1895.

2) Kraupa-

Runke, M.: Pervenöse Geruchs und Geschmachse. mpfindungen nach Neosalvarsan injektion Munch, med, Wschr., 63: 46, 1916. 3) Bednär, M.u., Langfelder, O.: Über das intravenöse(hämatoge. ne) Riechen, Mschr, Ohr, hk, 64:1133, 1930. 4)

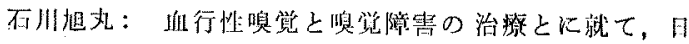

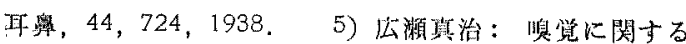

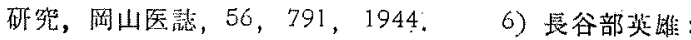

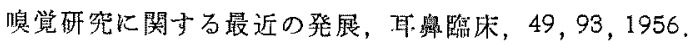

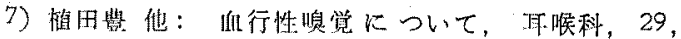

547,1957 ８）大沢林之助 他：咱覚障害に対する丁 リナミン静注使用の臨床的考察，耳㬋科，29,513,1957,

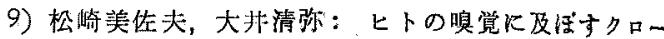

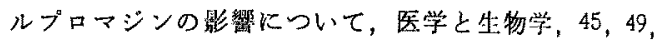

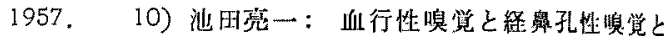
の相閣について，医学上生物学，45，49，1957。 11) 任 娟忠雄他：静脈内注射に由る嗅覚について，耳䀢科，

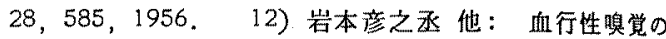

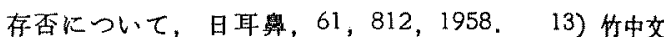
一郎 他：嗅覚の臨床的観察，耳喉科，30，1035, 1958 , 14）市原正蜼：嗅覚の臨床, 東京, 金原出版, 1963 , 15）林哲夫：家東に括ける嗅刺戙性呼吸反応知見，補 遗亚びに血管を介して惹起される咱営特にその発生僟序 について，十全医会誌，64，73，1960，16）渡辺疄： 家乘に扣ける冬眠麻酔時の㖵刺戟性呼吸反応，十全医会 誌，66，177，1960，17）梘陽一郎：経静脈性嗅覚

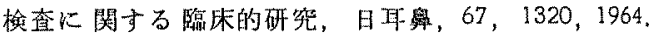
18）石井未之助，山田考：嗅覚からら友た哺乳動物の舞

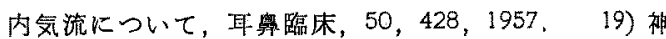

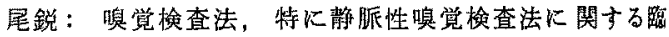

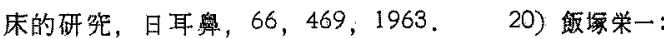

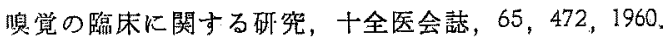

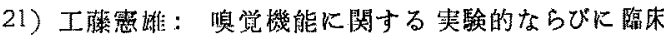

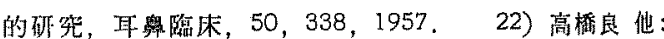

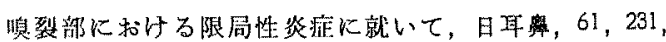
1958. 23) 中原邦昭：喚営障害に関する蹈床的研

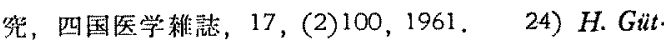
tich.: Über die klinische Bedeutung der Riechprüfung, Mschr, Ohr, hk, 98, 4, 1964 . 25) 木村元:

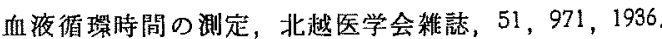

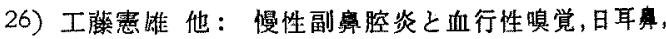
$61,777,1958$.

稆を終るに当り，本研究を命ぜられから指学 校閶を暘わつた恩師皚田教授に感謝すると其に。 䒠䮖に際し終始多大の有益なる指学助害をいた だいた惟的助教授に御礼的し上げます。

な扰本踰交の要旨は第 4 回副腔学会，第 45 回十全医学全，第 67 回日本耳鼻㸶㮢科学会 学術講演会に扣いて発表した。

（原穆到着＝昭和 41.5 .2 日） 